\title{
The Monitoring of Selected Heavy Metals Content and Bioavailability in the Soil-Plant System and Its Impact on Sustainability in Agribusiness Food Chains
}

\author{
Melánia Feszterová ${ }^{1, *(\mathbb{D})}$, Lýdia Porubcová ${ }^{1}$ and Anna Tirpáková ${ }^{1,2} \mathbb{D}$ \\ 1 Faculty of Natural Science, Constantine the Philosopher University in Nitra, Tr. A. Hlinku 1, \\ 94901 Nitra, Slovakia; lydia.porubcova@gmail.com (L.P.); atirpakova@ukf.sk (A.T.) \\ 2 Department of School Education, Faculty of Humanities, Tomas Bata University in Zlín, Štefáníkova 5670, \\ 76001 Zlín, Czech Republic \\ * Correspondence: mfeszterova@ukf.sk; Tel.: +421-903-456-414
}

Citation: Feszterová, M.; Porubcová, L.; Tirpáková, A. The Monitoring of Selected Heavy Metals Content and Bioavailability in the Soil-Plant System and Its Impact on Sustainability in Agribusiness Food Chains. Sustainability 2021, 13, 7021. https://doi.org/10.3390/su13137021

Academic Editor: Antonino Galati

Received: 11 May 2021

Accepted: 20 June 2021

Published: 22 June 2021

Publisher's Note: MDPI stays neutral with regard to jurisdictional claims in published maps and institutional affiliations.

Copyright: (c) 2021 by the authors. Licensee MDPI, Basel, Switzerland. This article is an open access article distributed under the terms and conditions of the Creative Commons Attribution (CC BY) license (https:// creativecommons.org/licenses/by/ $4.0 /)$.

\begin{abstract}
This study assisted in identifying and preventing the increase in heavy metals in soil and winter wheat. Its accumulation can affect cultivated crops, quality and crop yields, and consumers' health. Selected heavy metals were analyzed using the GTAAS method. They were undertaken on selected heavy metals content $(\mathrm{Cd}, \mathrm{Cu}, \mathrm{Pb}$, and $\mathrm{Zn})$ in arable soils at three sites in Slovakia and their accumulation in parts of cultivated winter wheat. Our study showed that the limit value of $\mathrm{Cd}$ in soil samples was exceeded in the monitored arable soils from 2017-2019. The average content values of $\mathrm{Cu}$ and $\mathrm{Zn}$ did not exceed the limit values, even in $\mathrm{Pb}$ values (except for the spring period). The analyses also showed that the heavy metals content for plants bioavailable in soil did not exceed the statutory critical values for $\mathrm{Cd}, \mathrm{Cu}$, and $\mathrm{Zn}$ 's average content values. However, $\mathrm{Pb}$ content exceeded permitted critical values. Heavy metals bioaccumulation $(\mathrm{Zn}, \mathrm{Cu})$ was within the limit values in wheat. Analyzed $\mathrm{Cd}$ content in wheat roots and $\mathrm{Pb}$ content were determined in all parts of wheat except grain. The study showed that grain from cultivated winter wheat in monitored arable soils is not a risk for consumers.
\end{abstract}

Keywords: heavy metal; bioavailability; winter wheat; sustainable agriculture; health; Wilcoxon rank-sum test; Kruskal-Wallis test; Spearman's rank correlation coefficient

\section{Introduction}

According to the European Union Agency for the Protection of the Environment, heavy metals are one of the primary pollutants in soil and are being considered a severe environmental issue [1,2]. Soil quality is crucial for crop production (it determines the possible composition of food and supported nutrient intake through the root system), human health [3-8], and the sustainability of ecosystems [2]. Interest in local organic food has increased in developed countries. Therefore, it is crucial to be aware of the spatial distribution and concentrations of toxic and potentially toxic elements in soils [9-14] and their transport to plants [15-18].

Although much progress has been achieved in understanding the links between soil and human health, we still do not have much knowledge about the complex interactions between them. Therefore, research in this area is still needed [2].

\subsection{Heavy Metals in Soil-Plant Systems}

Factors affecting the process of soil contamination and thus sustainable agriculture are, for example: human activity, the organic carbon content in the soil, $\mathrm{pH}$, available phosphorus, soil structure, and the capacity of exchangeable cations [19-23]. Soil contamination can damage and cause deterioration of water quality and have a negative impact on the environment [24-26]. Many studies have found that land-use change [27], cultivated plants, 
surrounding transport networks and hydrology of the territory [28,29], diversity of land use [30], and different ways of maintaining the soil are related to soil contamination [27-33].

Although plants need some heavy metals (e.g., $\mathrm{Cu}$ and $\mathrm{Zn}$ ) for their growth and development, excessive amounts of these elements can be toxic for them [34]. Excessive concentrations of certain heavy metals (e.g., $\mathrm{Cu}$ and $\mathrm{Zn}$ ) that contaminate the soil usually reduce plant growth and the soil's biological activity, ultimately leading to the loss of organic elements in the soil [35,36]. Functional groups of organic substances (alcohols, phenols, carbonyl groups, and carboxyl groups) can dissociate their hydrogen ions and separate metal cations by chelation $[37,38]$. If the organic elements added to the soil remain stable, the chelated metals will remain immobilized in the soil. However, organic acids, able to form soluble complexes with heavy metals, could increase the mobility of these heavy metals [39]. Changes within the soil can have different effects on metal mobility and bioavailability for plants [40-43].

Heavy metals such as $\mathrm{Cd}, \mathrm{Pb}, \mathrm{Hg}$, and As are globally dangerous environmental contaminants $[44,45]$. Their effect on plants causes typical signs of toxicity and an overall decrease in biomass with a potential reduction in yields [46]. The plant fights against the toxicity of heavy metals by activating enzymes eliminating reactive oxygen species [47], and by accumulating compounds that increase the chelation or sequestration of heavy metals [48]. As reported by Chandrasekaran et al., the toxicity and mobility of heavy metals in the soil ecosystem depends on factors such as the total concentration of heavy metals, the specific chemical form, and the binding status of the elements and its properties [49]. Identifying the relationships between soil properties and plant absorption regarding heavy metals can be used as a basis for setting soil guideline values to ensure the protection of human health from crop consumption, and to promote compliance with food standards $[9,50]$ and sustainable agriculture.

\subsection{Chemical and Toxicological Aproperties of Selected Contaminants}

Cadmium belongs to the group of cumulative metals and, if the concentration is exceeded, it has a toxic effect on both plant and animal organisms [46,51]. Cd in agricultural soils can be transferred to crops very easily which creates a potential health risk to consumers [9]. Concerning plant foods, the highest concentrations are present in cereals (e.g., wheat - especially whole grains) and rice, leafy vegetables, potatoes, and root vegetables [52,53]. Cadmium is a potentially toxic risk element, as it naturally occurs as an impurity in many phosphate fertilizers $[9,45,54]$.

Copper is one of the essential trace elements for plant and animal organisms and plays a role in basic physiological processes $[46,55]$. This metal can accumulate in the soil due to human activity [56]. While an excess of copper inhibits plant growth and impairs critical cellular processes [57], it acts as both an antioxidant and a prooxidant [58].

Lead enters the soil via anthropogenic sources (leaded petrol, lead-based paint, lead mining and smelting, and other industrial activities) [59]. Therefore, soil is consequently one of the largest contaminants $[59,60]$. Lead is a bioaccumulative toxic element, which does not degrade in the environment. Plants take up $\mathrm{Pb}$ only in minimal amounts and it is stored mainly in their roots [61]. Pb has a phytotoxic effect only at very high concentrations (from $100 \mathrm{ppm}$ to $500 \mathrm{ppm}$ ) [60,62]. Due to the toxicity of lead ( $\mathrm{Pb}$ ) compounds, its intake from food is one of the riskiest $[46,63]$. The most common source of $\mathrm{Pb}$ exposure for humans is the ingestion of contaminated food and drinking water [46,63-65].

Higher concentrations of nutrients such as Fe and $\mathrm{Zn}$ present in foods can harm the human body $[11,66]$. Zinc in the optimal concentration interval is one of the essential elements for plant and animal organisms [46]. The primary source of $\mathrm{Zn}$ in the soil is geo-logical material $[67,68]$. Contamination by zinc can be affected by surface horizons (fertilizer addition) [69] and soil unit. In addition to its existence as a free element or chelate complex in soil solution, $\mathrm{Zn}$ can be adsorbed on the surface of solid particles [70].

Many studies have shown the differing nature of the composition of plant pollution by risk elements in soils, including their transition from soil to plants $[1,6,11,17,20,43,63,68]$. 
However, only a few studies have analyzed soil units and heavy metal mobility in them. Moreover, very few researchers have explored the combined effect of mobility of heavy elements in soil units in the agricultural literature and compared their transition in selected parts of the plants. Therefore, our study's originality is in that it shows the mobility of heavy metals in soil units and their transition to cultivated plants.

This study aim was to analyze the content of selected heavy metals $(\mathrm{Cd}, \mathrm{Cu}, \mathrm{Pb}, \mathrm{Zn})$ in agricultural land in three selected localities in Slovakia (the cadastre of the municipality of Zlaté Moravce, Nitra region). The achieved results were compared in the years 2017-2019 in different periods (spring and autumn) in selected soil sampling depths. Analyzed soil samples from selected localities (Localities I-III) represent soil units in which correlations between heavy metal contents $(\mathrm{Cd}, \mathrm{Cu}, \mathrm{Pb}, \mathrm{Zn})$ were analyzed. The values of selected factors ( $\mathrm{pH}$ and TOC) and their influence on the mobility of heavy metals in the soil in two seasons and three selected localities were monitored. In the agricultural land-plants system, the determined heavy metals affect the cultivated crop. The content of heavy metals in plant samples (root, stem, leaves, and grain) of winter wheat can cause hygienic defects. Therefore, we investigated the transfer of selected heavy metals to individual parts of the cultivated crop (winter wheat), focusing on sustainable agriculture and the quality of cultivated plants.

\section{Materials and Methods}

\subsection{Study Area}

The measurements were carried out at 3 different sites (Localities I-III) to 5 depths (Table 1), in the Zlaté Moravce district (the Nitra region, the southwestern part of Slovakia) in the northwestern part of the Hronská Hills (Figure 1). We focused on sites within one district (Zlaté Moravce) to show the differences in heavy metal content and monitored parameters of arable soil.

Table 1. Zlaté Moravce-Prílepy: monitored area of soil sampling.

\begin{tabular}{ccccc}
\hline Localities & Coordinates & Type of Land & Use of Sites & $\begin{array}{c}\text { Soil Unit Designation } \\
\text { According to BPEJ } \mathbf{1}^{\prime}\end{array}$ \\
\hline Locality I & $\begin{array}{c}48^{\circ} 21^{\prime} 53.5^{\prime \prime} \mathrm{N} \\
18^{\circ} 24^{\prime} 59.4^{\prime \prime} \mathrm{E}\end{array}$ & Arable land & For growing wheats & $\begin{array}{c}\text { Brown soils typical, on loess, medium } \\
\text { (moderate)-heavy }\end{array}$ \\
\hline Locality II & $\begin{array}{l}48^{\circ} 22^{\prime} 01.1^{\prime \prime} \mathrm{N} \\
18^{\circ} 24^{\prime} 55.6^{\prime \prime} \mathrm{E}\end{array}$ & Arable land & For growing wheats & $\begin{array}{c}\text { Brown soils (type) on } \\
\text { loess clays, heavy }\end{array}$ \\
\hline Locality III & $48^{\circ} 22^{\prime} 25.3^{\prime \prime} \mathrm{N}$ & Arable land & For growing wheats & $\begin{array}{c}\text { Brown soils typical, on loess, medium } \\
\text { (moderate)-heavy }\end{array}$ \\
\hline
\end{tabular}

${ }^{1}$ [71] designation according to BPEJ (BPEJ is the soil evaluation method on the territory and nationally used table for classifying how land is used). For example: brown soils typical, on loess, medium (moderate)-heavy is classified as number 44, which classifies its parts, structure, system of updating, and its use by evaluation of soil. BPEJ: Categorization of soil-ecological units.

Locality I corresponded to arable soil borders in the east with a small wood and in the west it borders the suburb of Zlaté Moravce-Prílepy. Locality II is located north-northeast of the suburb of Zlaté Moravce-Prílepy. The arable soil examined from Locality III was adjacent to the 1st class road no. 65 .

Most of the Zlaté Moravce (Zlate Moraveths) cadastre is on the Danubian Upland but its eastern part lies in Pohronský Inovec (Pohrone Inoveth) [72], in the valley of the Žitava River (Zhitava) on the border of western and central Slovakia [73]. It is located in the lowlands (170-300 $\mathrm{m}$ above sea level) [72].

Young tertiary clays, siltstones, and gravelly formations with artesian water horizons form a flat piece of land and spread to the hilly area on the Pohronská and Žitavská hill (pahorkatina) and the slopes of Pohronský Inovec. Of the pedological conditions, on the surface, there were Quaternary loess, clays, and river sediments (leached brown soils and alluvial soils) [73]. On the loess of the hills were brown soils along with the Žitava River alluvial soils of Fluvisols. Brown forest soils of Cambisols predominate in Tribeč and 
Pohronský Inovec [73]. The floodplains were covered with modal to gley Fluvisols. These soils are deep, medium-heavy (loam) to heavy (clay-loam) soils. The agricultural area was dominated by high-quality deep clay brown soils and Luvisols, modal to Pseudogley. The most widespread soils in the foothills to mountainous areas were modal, Pseudogley, and Luvisol Cambisols. Soil types and subtypes of two soil groups predominate in the area, namely groups of leached soils and groups of brown soils: Brown soil (B), Luvisol (LV), and Cambisol (CM) [74].

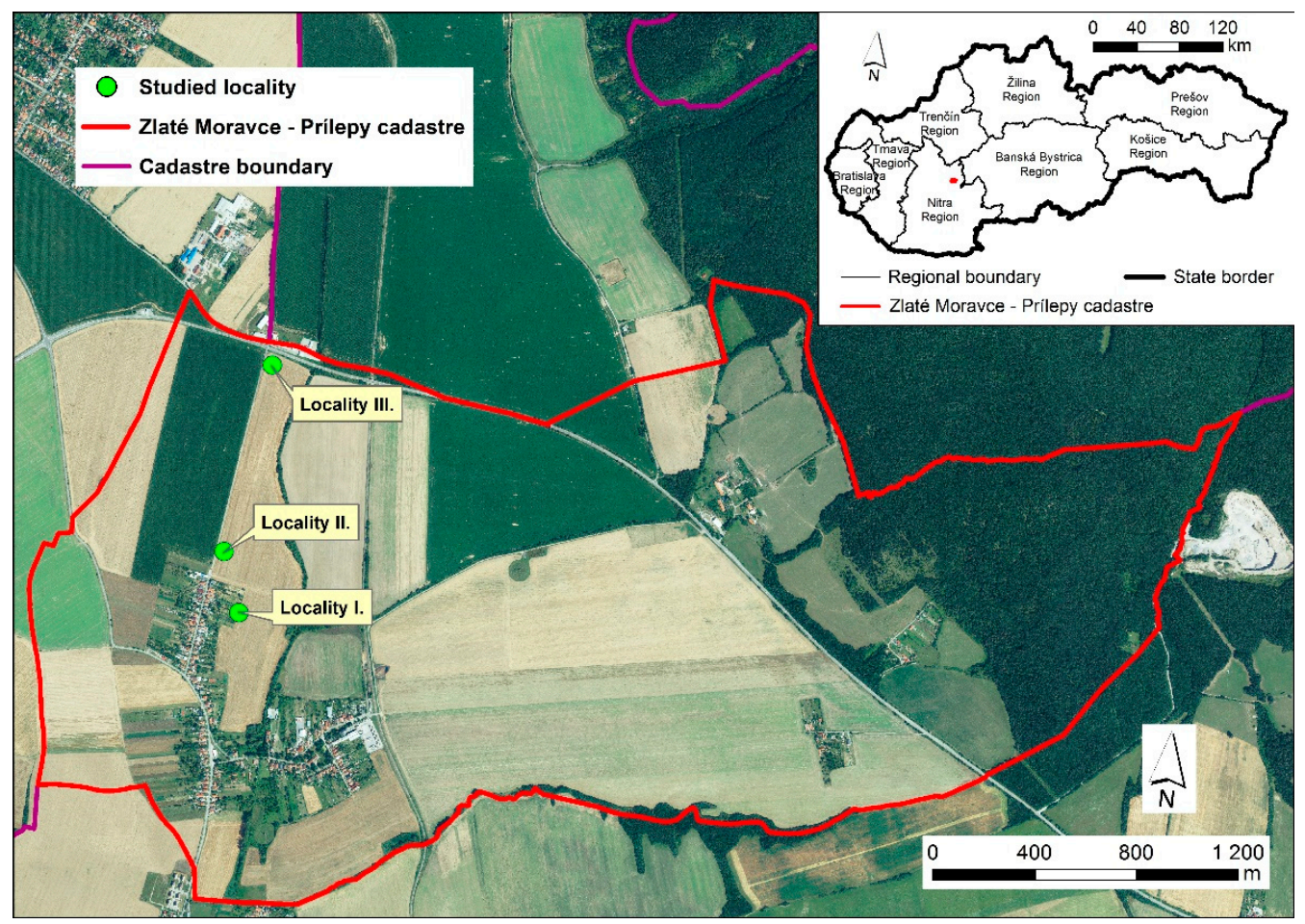

Figure 1. Monitored area (Localities I-III).

The Zlaté Moravce district's climatic characteristic belonged to the European-continental climate area of the temperate zone with ocean air, which is transformed into continental. The Zlaté Moravce region is one of the warmest regions in Slovakia [72]. The lowland part belongs to the warm part; the mountains to the moderately warm climatic region [73]. The flow of air masses is conditioned by the area's morphology, with prevailing east and northwest winds. Average temperatures in the monitored areas ranged from $-6.4{ }^{\circ} \mathrm{C}$ to $23.1^{\circ} \mathrm{C}$.

\section{Monitored Sites (Localities I-III)-Arable Lands for Cultivating Cereals}

Fertilization via $200 \mathrm{~kg} \cdot \mathrm{ha}^{-1}$ NPK (a purely natural organic fertilizer which contains N $5 \%$, P $2 \%, \mathrm{~K} 8 \%)$, sowing, $200 \mathrm{~kg} \cdot \mathrm{ha}{ }^{-1} \mathrm{LAV}\left(\mathrm{NH}_{4} \mathrm{NO}_{3}\right.$ with limestone, pure content of $\mathrm{N}$ is $27 \%), 200 \mathrm{~kg} \cdot \mathrm{ha}^{-1} \mathrm{LAV}$, and $120 \mathrm{~kg} \cdot \mathrm{ha}^{-1} \mathrm{LAV}$, was applied along with the fungicide Hutton to the monitored arable lands (Localities I-III) before the cultivation of wheat durum (Triticum durum) (autumn 2016/spring 2017). After machine harvesting, the crushed straw was incorporated into the soil.

Canola oil (Brassica napus L.) was grown at Locality I (autumn 2017/spring 2018), sowing, $200 \mathrm{~kg} \cdot \mathrm{ha}^{-1} \mathrm{NPK}$, herbicide Butisan $400 \mathrm{SC}$, fungicide Albukol, in spring, $200 \mathrm{~kg} \cdot \mathrm{ha}^{-1}$ DAM (DAM = liquid nitrogen fertilizer), $180 \mathrm{~kg} \cdot \mathrm{ha}^{-1} \mathrm{LAV}, 100 \mathrm{~kg} \cdot \mathrm{ha}^{-1}$ DAM 390 (DAM $390=$ liquid nitrogen fertilizer contains $30 \%$ nitrogen) and boron $1 \mathrm{~kg}$, fungicide Pictor, Boscalid, 2x insecticide Decis ew 50, and insecticide Nurelle D.

Within Locality II and Locality III (autumn 2017/spring 2018), after ploughing $200 \mathrm{~kg} \cdot \mathrm{ha}^{-1}$ NPK, sowing wheat durum (Triticum durum), $200 \mathrm{~kg} \cdot \mathrm{ha}^{-1} \mathrm{LAV}, 200 \mathrm{~kg} \cdot \mathrm{ha}^{-1} \mathrm{LAV}$, 
$120 \mathrm{~kg} \cdot \mathrm{ha}^{-1} \mathrm{LAV}$, the Hutton fungicide was applied. After machine harvesting, the crushed straw was incorporated into the soil.

After ploughing, $180 \mathrm{~kg} \cdot \mathrm{ha}^{-1} \mathrm{NPK}$, the sowing of wheat (Triticum aestivum L.) (autumn 2018/spring 2019), $150 \mathrm{~kg} \cdot \mathrm{ha}^{-1} \mathrm{LAV}, 200 \mathrm{~kg} \cdot \mathrm{ha}^{-1} \mathrm{LAV}, 200 \mathrm{~kg} \cdot \mathrm{ha}^{-1} \mathrm{LAV}$, the Hutton fungicide, Tebuconzole, and insecticide Markate 50 were applied. After mechanical harvesting, the straw was incorporated into the soil. At the end of the summer, and at the beginning of autumn 2018, Localities I-III, the sowing of Canola oil (Brassica napus L.) took place, utilizing $200 \mathrm{~kg} \cdot \mathrm{ha}^{-1}$ NPK fertilizer.

\subsection{Equipment and Analytical Procedure}

The heavy metal analysis included a series of measurements carried out from spring 2017-autumn 2019. During this period, 240 soil samples were taken from 3 selected localities (soil units), which were used as arable land (Localities I-III). Soil samples were taken from 5 depths (from $0.0 \mathrm{~m}$ to $0.5 \mathrm{~m}$ ). The analysis of all soil samples, e.g., $\mathrm{pH}$ $\left(\mathrm{pH}\left(\mathrm{H}_{2} \mathrm{O}, \mathrm{pH}(\mathrm{KCl})\right)\right.$ and TOC were repeated three times. From the analyzed soil samples, we obtained the total content of heavy metals $(\mathrm{Cd}, \mathrm{Cu}, \mathrm{Pb}$, and $\mathrm{Zn})$ and the values of heavy metal content to the bioavailability of plants, which we evaluated based on permitted limit values. The contents of selected heavy metals $(\mathrm{Cd}, \mathrm{Cu}, \mathrm{Pb}$, and $\mathrm{Zn})$ were analyzed in various parts of the plants' material. The transition of heavy metals into the soil-plant system was monitored in durum wheat (Triticum durum) (for analyses, the following were examined: root, stalk, leaf, and grain from Localities I-III).

According to the Decree of the Ministry of Labour, Social Affairs and Family of the Slovak Republic No. 59/2013 Coll. and subsequent amendments for contamination detection, at least one average sample was taken from every area of 10 ha (at least 9 sampling points/places) with homogeneous soil in the area under examination [75]. For heterogeneous soil in the mentioned area, average samples were taken from each part. For analytical determination of heavy metal limit values, we used air-dried soil samples, sieved to fine soil with a particle size below $2 \mathrm{~mm}$. First, the soil samples were analyzed in an aqua regia solution. The results were analyzed in accordance with the Decree of the Ministry of Agriculture and Rural Development of the Slovak Republic No. 508/2004 Coll. and with an amendment of certain acts [76].

In accordance with van Reeuwijk, we analyzed $\mathrm{pH}$ values in soil samples (water to soil $=2.5: 1, \mathrm{v}: \mathrm{m})$ [77]. We determined an active soil reaction $\left(\mathrm{pH}\left(\mathrm{H}_{2} \mathrm{O}\right)\right.$ ) in distilled water and an exchange soil reaction $(\mathrm{pHKCl})$ in a solution of $1 \mathrm{~mol} \cdot \mathrm{dm}^{-3} \mathrm{KCl}$ (Centralchem, Ltd.; Bratislava, Slovakia). The solution was mixed. The suspension was shaken in a Unimax 2010 horizontal shaker (Heidolph Instrument, GmbH, Schwabach, Germany) for $20 \mathrm{~min}$. After shaking, the samples were filtered through filter paper Filtrak 390 (Munktell \& Filtrak, $\mathrm{GmbH}$, Bärenstein, Germany) and measured by a pH meter (inoLab Multi 9310 SET I; Labo SK, Ltd., Bratislava, Slovakia). In all experiments, the chemical reagents (ACS grade) were dissolved using distilled and deionized (DDI) water produced using a MilliporeSigma ${ }^{\mathrm{TM}}$ Synergy $^{\mathrm{TM}}$ Ultrapure Water Purification System (Meck Millipore, Bedford, MA, USA).

According to the Tjurin method modified by Nikitina, we determined the total organic carbon content (TOC) in soil samples and the various separated fractions [78]. From the equation DH $=\mathrm{CHA} / \mathrm{TOC} .100[\%]$, we calculated the humification degree of humified substances [79].

For the determination of metal content $(\mathrm{Cd}, \mathrm{Pb}, \mathrm{Cu}$, and $\mathrm{Zn})$, we used atomic absorption spectroscopy (GT AAS; Agilent Technologies, GTA 120 Graphite Tube Atomizer, Hermes LabSystems, Ltd.; Bratislava, Slovakia). Soil samples were measured in duplicate in a Graphite Atomic Absorption Spectrophotometer for $\mathrm{Cd}, \mathrm{Cu}, \mathrm{Pb}$, and $\mathrm{Zn}$ quantification. Compound samples were mineralized before analysis (Ethos One; Chromspec Slovakia, Ltd., Šal'a, Slovakia). Soil samples were mineralized in aqua regia $\left(\mathrm{HCl}=37 \% ; \mathrm{HNO}_{3}\right.$ p.a. $\geq 65 \%$; chemicals from Sigma Aldrich, Ltd.; Bratislava, Slovakia) for determining the content of risk elements. Soil samples were extracted in $\mathrm{NH}_{4} \mathrm{NO}_{3}$ for the contents of bioavailable forms of heavy metals. 
In plant samples (leaf, root, and stalk of wheat winter grain), heavy metals $(\mathrm{Cd}, \mathrm{Pb}$, $\mathrm{Cu}$, and $\mathrm{Zn}$ ) were measured in duplicate by the GT AAS method [80]. The plant parts were dried at room temperature, mineralized in an extract of $\mathrm{HNO}_{3}$ and $\mathrm{H}_{2} \mathrm{O}_{2}\left(\mathrm{HNO}_{3} \geq 65 \%\right.$; $67 \% ; \mathrm{H}_{2} \mathrm{O}_{2} \geq 30 \%$; from Sigma Aldrich, Ltd., Bratislava, Slovakia). We used the leaching method with $1 \mathrm{~mol} \cdot \mathrm{dm}^{-3} \mathrm{NH}_{4} \mathrm{NO}_{3}\left(\mathrm{NH}_{4} \mathrm{NO}_{3} \geq 98 \%\right.$; Sigma Aldrich, Ltd.; Bratislava, Slovakia) to determine the selected risk elements' content $(\mathrm{Cd}, \mathrm{Cu}, \mathrm{Pb}, \mathrm{Zn})$ accessible to plants.

\subsection{Statistical Analysis}

As previously mentioned, the measured values obtained from soil samples were analyzed using selected statistical methods. Specifically, to verify the normality of the sample distribution, the Shapiro-Wilk test was chosen. We used the Wilcoxon two-sample test to confirm the statistical significance of the differences between the sampling periods (spring and autumn). In the following analysis, we used the Kruskal-Wallis test. To calculate the degree of interdependence between the observed variables, the Spearman's rank correlation coefficient was applied [81]. We performed the calculations in the STATISTICA program 9.0 Standard Plus CZ (StatSoft Inc., Tulsa, OK, USA).

The null hypothesis $\mathrm{H}_{0}$ was tested against the alternative hypothesis: $\mathrm{H}_{1}$. The samples are not from the same population, i.e., there are significant differences between variables. The $p$-value expresses the probability of error if the null hypothesis is rejected in favor of the alternative hypothesis: $\mathrm{H}_{1}$. If this probability is smaller than 0.05 resp. 0.01 , the tested hypothesis $\mathrm{H}_{0}$ is rejected at the significance level $\alpha=0.05$ resp. $\alpha=0.01$. Otherwise, we cannot reject the tested hypothesis $\mathrm{H}_{0}$.

\section{Results}

\subsection{Heavy Metals in Soil Units of Localities I-III}

At Localities I-III, soil samples were taken in two seasons (spring, autumn). As previously stated, we examined the content of heavy metals $(\mathrm{Cd}, \mathrm{Cu}, \mathrm{Pb}$, and $\mathrm{Zn})$ in the soil samples (Tables 2-4).

Based on the results (Tables 2-4), the limit value of cadmium $\left(0.70 \mathrm{mg} \cdot \mathrm{kg}^{-1}\right)$ was exceeded in all three arable lands in the observed periods (spring and autumn) between 20172019. The Cd contamination in arable lands in springs 2017-2019 decreased as follows: Locality I $\left(1.33 \mathrm{mg} \cdot \mathrm{kg}^{-1}\right.$; excess by $\left.90 \%\right)>$ Locality III $\left(1.31 \mathrm{mg} \cdot \mathrm{kg}^{-1}\right.$; excess by $\left.87.1 \%\right)>$ Locality II $\left(1.28 \mathrm{mg} \cdot \mathrm{kg}^{-1}\right.$; excess by $\left.82.9 \%\right)$. The lowest $\mathrm{Cd}$ concentration during the observed spring periods was at Locality I (in 2017 depth $0.2-0.3 \mathrm{~m}$ and 2018 depth $0.3-0.4 \mathrm{~m}$ ) and at Locality II (in 2019 depths $0.2-0.3 \mathrm{~m}$ and $0.4-0.5 \mathrm{~m}$ ). Below limit, Cd concentrations were recorded at Locality I in $2018\left(0.60 \mathrm{mg} \cdot \mathrm{kg}^{-1}\right.$, depth $\left.0.4-0.5 \mathrm{~m}\right)$ and Locality II in 2019 $\left(0.40 \mathrm{mg} \cdot \mathrm{kg}^{-1}\right.$, depth $\left.0.3-0.4 \mathrm{~m}\right)$. The highest $\mathrm{Cd}$ concentration was found in spring 2019 at Locality I (2.40 mg. $\mathrm{kg}^{-1}$, depth $\left.0.3-0.4 \mathrm{~m}\right)$.

Table 2. The content of heavy metals $\left(\mathrm{mg} \cdot \mathrm{kg}^{-1}\right)$ at Locality I.

\begin{tabular}{cccccccccc}
\hline Metal Concentration & \multicolumn{2}{c}{2017} & \multicolumn{2}{c}{$\mathbf{2 0 1 8}$} & \multicolumn{2}{c}{$\mathbf{2 0 1 9}$} \\
\hline Spring & Ave \pm SD & Min & Max & Ave \pm SD & Min & Max & Ave \pm SD & Min & Max \\
\hline $\mathrm{Cd}$ & $1.32 \pm 0.59$ & 0.20 & 1.80 & $0.96 \pm 0.48$ & 0.20 & 1.40 & $1.72 \pm 0.48$ & 1.20 & 2.40 \\
$\mathrm{Cu}$ & $16.00 \pm 1.39$ & 14.40 & 17.60 & $19.68 \pm 0.57$ & 19.00 & 20.60 & $19.04 \pm 2.82$ & 16.00 & 24.40 \\
$\mathrm{~Pb}$ & $45.60 \pm 6.12$ & 36.00 & 54.00 & $56.76 \pm 1.82$ & 54.94 & 59.94 & $65.68 \pm 3.01$ & 62.52 & 70.56 \\
$\mathrm{Zn}$ & $51.91 \pm 2.37$ & 48.52 & 54.82 & $71.20 \pm 5.88$ & 64.00 & 80.00 & $63.20 \pm 16.33$ & 38.00 & 80.00 \\
\hline Autumn & Ave $\pm \mathrm{SD}$ & Min & Max & Ave $\pm \mathrm{SD}$ & Min & Max & Ave \pm SD & Min & Max \\
\hline $\mathrm{Cd}$ & $2.32 \pm 0.48$ & 1.40 & 2.80 & $1.52 \pm 0.10$ & 1.40 & 1.60 & $0.92 \pm 0.39$ & 0.40 & 1.60 \\
$\mathrm{Cu}$ & $20.48 \pm 2.33$ & 18.40 & 25.00 & $19.88 \pm 1.72$ & 18.20 & 22.60 & $18.92 \pm 0.49$ & 18.40 & 19.80 \\
$\mathrm{~Pb}$ & $59.42 \pm 14.72$ & 47.70 & 87.90 & $58.64 \pm 8.01$ & 49.50 & 70.92 & $44.9 \pm 7.83$ & 34.96 & 52.40 \\
$\mathrm{Zn}$ & $55.20 \pm 14.73$ & 46.00 & 84.00 & $60.00 \pm 11.10$ & 40.00 & 74.00 & $52.40 \pm 9.91$ & 40.00 & 66.00 \\
\hline
\end{tabular}


Table 3. The content of heavy metals $\left(\mathrm{mg} \cdot \mathrm{kg}^{-1}\right)$ at Locality II.

\begin{tabular}{|c|c|c|c|c|c|c|c|c|c|}
\hline \multirow{2}{*}{$\frac{\text { Metal Concentration }}{\text { Spring }}$} & \multicolumn{3}{|c|}{2017} & \multicolumn{3}{|c|}{2018} & \multicolumn{3}{|c|}{2019} \\
\hline & Ave $\pm S D$ & Min & Max & Ave $\pm S D$ & Min & Max & Ave $\pm S D$ & Min & Max \\
\hline $\mathrm{Cd}$ & $1.56 \pm 0.15$ & 1.40 & 1.80 & $1.48 \pm 0.16$ & 1.20 & 1.60 & $0.80 \pm 0.67$ & 0.20 & 1.80 \\
\hline $\mathrm{Cu}$ & $16.96 \pm 0.70$ & 16.00 & 18.00 & $21.28 \pm 0.92$ & 20.00 & 22.80 & $20.96 \pm 0.82$ & 20.00 & 22.00 \\
\hline $\mathrm{Pb}$ & $46.00 \pm 6.32$ & 38.00 & 56.00 & $54.80 \pm 7.76$ & 46.00 & 66.00 & $79.60 \pm 2.94$ & 76.00 & 84.00 \\
\hline $\mathrm{Zn}$ & $54.692 \pm 2.02$ & 52.36 & 56.94 & $62.05 \pm 3.49$ & 57.06 & 67.18 & $63.56 \pm 2.65$ & 60.28 & 66.54 \\
\hline Autumn & Ave \pm SD & Min & Max & Ave \pm SD & Min & $\operatorname{Max}$ & Ave \pm SD & Min & Max \\
\hline $\mathrm{Cd}$ & $2.48 \pm 0.32$ & 2.00 & 2.80 & $1.68 \pm 0.10$ & 1.60 & 1.80 & $1.16 \pm 0.23$ & 0.80 & 1.40 \\
\hline $\mathrm{Cu}$ & $21.60 \pm 0.66$ & 20.40 & 22.40 & $19.68 \pm 0.81$ & 18.60 & 20.40 & $19.72 \pm 1.12$ & 18.00 & 21.00 \\
\hline $\mathrm{Pb}$ & $47.20 \pm 3.25$ & 42.00 & 52.00 & $65.60 \pm 14.11$ & 38.00 & 78.00 & $70.40 \pm 4.96$ & 66.00 & 80.00 \\
\hline $\mathrm{Zn}$ & $61.80 \pm 5.89$ & 54.76 & 72.58 & $65.22 \pm 8.04$ & 54.92 & 74.66 & $55.24 \pm 6.94$ & 45.04 & 63.20 \\
\hline
\end{tabular}

Notice: Ave \pm SD $=$ Average \pm Standard Deviation. Min $=$ min. value; Max $=$ max. value

Table 4. The content of heavy metals $\left(\mathrm{mg} \cdot \mathrm{kg}^{-1}\right)$ at Locality III.

\begin{tabular}{cccccccccc}
\hline Metal Concentration & \multicolumn{2}{c}{2017} & \multicolumn{2}{c}{$\mathbf{2 0 1 8}$} & \multicolumn{2}{c}{$\mathbf{2 0 1 9}$} \\
\hline Spring & Ave \pm SD & Min & Max & Ave \pm SD & Min & Max & Ave \pm SD & Min & Max \\
\hline $\mathrm{Cd}$ & $1.44 \pm 0.41$ & 1.00 & 2.20 & $1.44 \pm 0.27$ & 1.00 & 1.80 & $1.04 \pm 0.23$ & 0.80 & 1.40 \\
$\mathrm{Cu}$ & $14.56 \pm 12.60$ & 12.60 & 16.00 & $19.40 \pm 2.90$ & 15.60 & 22.40 & $18.60 \pm 1.99$ & 15.80 & 20.60 \\
$\mathrm{~Pb}$ & $41.60 \pm 3.88$ & 36.00 & 46.00 & $52.00 \pm 4.90$ & 44.00 & 58.00 & $77.60 \pm 1.96$ & 76.00 & 80.00 \\
$\mathrm{Zn}$ & $48.30 \pm 2.69$ & 44.36 & 52.44 & $55.10 \pm 4.77$ & 49.28 & 61.12 & $57.20 \pm 2.81$ & 52.46 & 60.86 \\
\hline Autumn & Ave $\pm \mathrm{SD}$ & Min & Max & Ave \pm SD & Min & Max & Ave \pm SD & Min & Max \\
\hline $\mathrm{Cd}$ & $2.52 \pm 0.27$ & 2.00 & 2.80 & $1.60 \pm 0.13$ & 1.40 & 1.80 & $1.16 \pm 0.39$ & 0.80 & 1.80 \\
$\mathrm{Cu}$ & $17.52 \pm 0.98$ & 16.40 & 18.80 & $19.36 \pm 1.20$ & 17.40 & 21.00 & $18.44 \pm 2.29$ & 15.20 & 21.00 \\
$\mathrm{~Pb}$ & $41.60 \pm 4.96$ & 32.00 & 46.00 & $67.60 \pm 4.08$ & 62.00 & 74.00 & $65.60 \pm 5.57$ & 60.00 & 76.00 \\
$\mathrm{Zn}$ & $52.10 \pm 6.42$ & 44.64 & 62.70 & $58.08 \pm 4.74$ & 50.78 & 63.86 & $56.44 \pm 18.67$ & 33.84 & 86.66 \\
\hline
\end{tabular}

Notice: Ave $\pm \mathrm{SD}=$ Average \pm Standard Deviation. Min = min. value; Max = max. value.

Based on the average Cd values shown in Tables 2-4, it can be stated that in autumn periods, the $\mathrm{Cd}$ content in the examined arable lands decreased every year. The lowest Cd concentration during autumn periods was at Locality I in $2019\left(0.40 \mathrm{mg} \cdot \mathrm{kg}^{-1}\right.$, depth $0.0-0.1 \mathrm{~m})$; the highest $\mathrm{Cd}$ concentration was in $2017\left(2.80 \mathrm{mg} \cdot \mathrm{kg}^{-1}\right)$. The limit Cd value was exceeded in all three observed arable lands in autumn (2017-2019). The average Cd content in autumn in all the observed years was the highest at Locality II $\left(1.77 \mathrm{mg} \cdot \mathrm{kg}^{-1}\right.$; excess by $152.9 \%)>$ Locality III $\left(1.76 \mathrm{mg} \cdot \mathrm{kg}^{-1}\right.$; excess by $\left.151.4 \%\right)>$ Locality I $\left(1.59 \mathrm{mg} \cdot \mathrm{kg}^{-1}\right.$; excess by $127.1 \%)$.

As the soil samples' analyses indicated (Tables 2-4), they did not exceed the limit values of copper $\left(60 \mathrm{mg} \cdot \mathrm{kg}^{-1}\right)$ and zinc $\left(150 \mathrm{mg} \cdot \mathrm{kg}^{-1}\right)$ in any of the examined arable lands during any of the analyzed periods (spring and autumn) 2017-2019. The average $\mathrm{Cu}$ content at the localities decreased as follows: spring-Locality II $\left(19.73 \mathrm{mg} \cdot \mathrm{kg}^{-1}\right)>$ Locality I $\left(18.24 \mathrm{mg} \cdot \mathrm{kg}^{-1}\right)>$ Locality III $\left(17.52 \mathrm{mg} \cdot \mathrm{kg}^{-1}\right)$; autumn-Locality II $\left(20.33 \mathrm{mg} \cdot \mathrm{kg}^{-1}\right)>$ Locality I $\left(19.76 \mathrm{mg} \cdot \mathrm{kg}^{-1}\right)>$ Locality III $\left(18.44 \mathrm{mg} \cdot \mathrm{kg}^{-1}\right)$. The highest spring Cu concentration was recorded at Locality I $\left(24.40 \mathrm{mg} \cdot \mathrm{kg}^{-1}\right.$, depth $\left.0.4-0.5 \mathrm{~m}\right)$ in 2019 , while the lowest spring $\mathrm{Cu}$ concentration was found at Locality III $\left(12.60 \mathrm{mg} \cdot \mathrm{kg}^{-1}\right.$, depth $\left.0.3-0.4 \mathrm{~m}\right)$ in 2019. The lowest autumn $\mathrm{Cu}$ concentration was in 2019 at Locality III $\left(15.20 \mathrm{mg} \cdot \mathrm{kg}^{-1}\right.$, depth $0.4-0.5 \mathrm{~m}$ ), while the highest autumn $\mathrm{Cu}$ concentration was 2017 at Locality I (25.00 mg. $\mathrm{kg}^{-1}$, depth $0.0-0.1 \mathrm{~m}$ ).

The limit value of lead $\left(70 \mathrm{mg} \cdot \mathrm{kg}^{-1}\right)$ was exceeded in spring samples 2017-2019, while in autumn samples, the limit value was not exceeded (Tables 2-4). The $\mathrm{Pb}$ limit value in spring samples was exceeded as follows: at Locality I $\left(80.00 \mathrm{mg} \cdot \mathrm{kg}^{-1}\right.$, depth $0.3-0.4 \mathrm{~m} ; 76.00 \mathrm{mg} \cdot \mathrm{kg}^{-1}$, depth $\left.0.4-0.5 \mathrm{~m}\right)$, in spring 2018 and $2019\left(76.00 \mathrm{mg} \cdot \mathrm{kg}^{-1}\right.$, depth $0.2-0.3 \mathrm{~m} ; 72.00 \mathrm{mg} \cdot \mathrm{kg}^{-1}$, depth $0.3-0.4 \mathrm{~m} ; 80.00 \mathrm{mg} \cdot \mathrm{kg}^{-1}$, depth $0.4-0.5 \mathrm{~m}$ ); at Localities 
II and III in all the examined depths in spring 2019. The spring average Pb content in 2017-2019 decreased in the observed arable lands: Locality II $\left(60,13 \mathrm{mg} \cdot \mathrm{kg}^{-1}\right)>$ Locality I $\left(60.00 \mathrm{mg} \cdot \mathrm{kg}^{1}\right)>$ Locality III $\left(57.07 \mathrm{mg} \cdot \mathrm{kg}^{-1}\right)$. At Locality III, the spring average $\mathrm{Pb}$ content values decreased as follows: in $2019\left(77.60 \mathrm{mg} \cdot \mathrm{kg}^{-1}\right.$; exceeding the limit value by $10.9 \%)>2018\left(52.00 \mathrm{mg} \cdot \mathrm{kg}^{-1}\right)>2017\left(41.60 \mathrm{mg} \cdot \mathrm{kg}^{-1}\right)$. The lowest spring Pb concentration was recorded in 2017 at Locality I (depth $0.0-0.1 \mathrm{~m})$ and Locality III $\left(36.00 \mathrm{mg} \cdot \mathrm{kg}^{-1}\right.$, depth $0.3-0.4 \mathrm{~m}$ ). The highest spring Pb concentration was found in 2019 at Locality II (84.00 $\mathrm{mg} \cdot \mathrm{kg}^{-1}$, depth $0.1-0.2 \mathrm{~m}$ ). Although the average values did not exceed the $\mathrm{Pb}$ limit value, in some autumn samples taken from various depths, the $\mathrm{Pb}$ contamination did exceed the limit value. At Locality III, in autumn samples, the average $\mathrm{Pb}$ content decreased as follows: $2018\left(67.60 \mathrm{mg} \cdot \mathrm{kg}^{-1}\right)>2019\left(65.60 \mathrm{mg} \cdot \mathrm{kg}^{-1}\right)>2017\left(41.60 \mathrm{mg} \cdot \mathrm{kg}^{-1}\right)$. The highest autumn $\mathrm{Pb}$ contamination was found at Locality I in $2017\left(84.00 \mathrm{mg} \cdot \mathrm{kg}^{-1}\right.$, depth $0.0-0.1 \mathrm{~m}$; exceeding the limit value by $20 \%$ ). The lowest autumn $\mathrm{Pb}$ contamination was recorded at Locality III ( $32.00 \mathrm{mg} \cdot \mathrm{kg}^{-1}$, depth $\left.0.2-0.3 \mathrm{~m}\right)$ in 2017 . The average autumn $\mathrm{Pb}$ content in $2017-2019$ decreased as follows: Locality II $\left(61.07 \mathrm{mg} \cdot \mathrm{kg}^{-1}\right)>$ Locality III $\left(58.27 \mathrm{mg} \cdot \mathrm{kg}^{-1}\right)>$ Locality I $\left(55.87 \mathrm{mg} \cdot \mathrm{kg}^{-1}\right)$.

The lowest spring zinc concentration in the observed arable lands was found at Locality III (44.36 mg $\mathrm{kg}^{-1}$, depth $0.3-0.4 \mathrm{~m}$ ) in 2017. At Locality I, the highest spring Zn concentration $\left(70.56 \mathrm{mg} \cdot \mathrm{kg}^{-1}\right.$, depth $0.4-0.5 \mathrm{~m}$ ) was recorded in 2019. The highest spring average Zn content during 2017-2019 was at Locality II $\left(60.10 \mathrm{mg} \cdot \mathrm{kg}^{-1}\right)>$ Locality I > $\left(58.12 \mathrm{mg} \cdot \mathrm{kg}^{-1}\right)>$ Locality III $\left(53.53 \mathrm{mg} \cdot \mathrm{kg}^{-1}\right)$. The highest autumn Zn concentration was re-corded at Locality I $\left(87.90 \mathrm{mg} \cdot \mathrm{kg}^{-1}\right.$, depth $\left.0.0-0.1 \mathrm{~m}\right)$ in 2017 ; the lowest autumn $\mathrm{Zn}$ concentration was at Locality III (33.84 mg. $\mathrm{kg}^{-1}$, depth $\left.0.4-0.5 \mathrm{~m}\right)$ in 2019 . The highest autumn average Zn content during 2017-2019 was at Locality II $\left(60.75 \mathrm{mg} \cdot \mathrm{kg}^{-1}\right)>$ Locality III (55.54 $\left.\mathrm{mg} \cdot \mathrm{kg}^{-1}\right)>$ Locality II $\left(54.32 \mathrm{mg} \cdot \mathrm{kg}^{-1}\right)$.

Correlations Analysis between Selected Heavy Metals Contents at Localities I-III

Using statistical methods, the correlations between the heavy metals' contents $(\mathrm{Cd}$, $\mathrm{Cu}, \mathrm{Pb}$, and $\mathrm{Zn}$ ) at Localities I-III were studied. The calculated values of the correlation coefficients are summarized in Table 5.

Table 5. Correlation coefficients between heavy metals contents $(\mathrm{Cd}, \mathrm{Cu}, \mathrm{Pb}$, and $\mathrm{Zn})$ at Localities I-III.

\begin{tabular}{|c|c|c|c|c|c|c|c|c|}
\hline & \multirow{2}{*}{$\frac{\text { Season }}{\text { Metal cont. }^{1}}$} & \multicolumn{3}{|c|}{ 2017-2019 (Spring) } & \multirow[b]{2}{*}{ Metal cont. ${ }^{1}$} & \multicolumn{3}{|c|}{ 2017-2019 (Autumn) } \\
\hline & & $\mathrm{Cu}$ & $\mathrm{Cd}$ & $\mathrm{Pb}$ & & $\mathrm{Cu}$ & $\mathrm{Cd}$ & $\mathrm{Pb}$ \\
\hline \multirow{3}{*}{ Locality I } & $\mathrm{Zn}$ & 0.5903 & -0.0277 & 0.6613 & $\mathrm{Zn}$ & 0.7037 & 0.0072 & 0.5885 \\
\hline & $\mathrm{Cu}$ & - & -0.4586 & 0.8088 & $\mathrm{Cu}$ & - & -0.0363 & 0.6697 \\
\hline & $\mathrm{Cd}$ & & - & -0.4947 & $\mathrm{Cd}$ & - & - & -0.3004 \\
\hline \multirow{3}{*}{ Locality II } & $\mathrm{Zn}$ & 0.9272 & -0.5375 & 0.5655 & $\mathrm{Zn}$ & 0.3516 & 0.1402 & 0.2478 \\
\hline & $\mathrm{Cu}$ & - & -0.4793 & 0.4919 & $\mathrm{Cu}$ & - & 0.5262 & -0.2480 \\
\hline & $\mathrm{Cd}$ & & - & -0.3224 & $\mathrm{Cd}$ & & - & -0.5971 \\
\hline \multirow{3}{*}{ Locality III } & $\mathrm{Zn}$ & 0.8704 & -0.2138 & 0.5653 & $\mathrm{Zn}$ & 0.8853 & -0.4627 & 0.4758 \\
\hline & $\mathrm{Cu}$ & - & -0.2929 & 0.4018 & $\mathrm{Cu}$ & - & -0.5501 & 0.5829 \\
\hline & $\mathrm{Cd}$ & - & - & -0.2977 & $\mathrm{Cd}$ & - & - & -0.7186 \\
\hline
\end{tabular}

${ }^{1}$ Metal cont. $=$ Metal contaminant.

Based on the results (Table 5) of the statistical analysis, it can be stated that there was a significant degree of correlation between the $\mathrm{Zn}$ and $\mathrm{Cu}$ contents $(\mathrm{r}=0.5903)$ and between the $\mathrm{Zn}$ and $\mathrm{Pb}$ contents $(\mathrm{r}=0.6613)$ in spring samples from Locality I. A high correlation degree $(r=0.8088)$ was recorded between the $\mathrm{Cu}$ and $\mathrm{Pb}$ contents. Based on the value of the correlation coefficient between $\mathrm{Zn}$ and $\mathrm{Cd}$ content, there was no significant correlation between them, and there were only a mild correlation degree between the other elements.

Between the $\mathrm{Zn}$ and $\mathrm{Cu}$ content in autumn samples from Locality I, the value of the correlation coefficient was $r=0.7037$, which means that the correlation was high between the contents of the examined elements. Between the $\mathrm{Zn}$ and $\mathrm{Pb}$ content $(\mathrm{r}=0.5885)$ and 
the $\mathrm{Cu}$ and $\mathrm{Pb}$ contents $(\mathrm{r}=0.6697)$ the correlation degree was significant. The correlations between the contents of the other elements were none or only mild.

The correlation coefficient between the $\mathrm{Zn}$ and $\mathrm{Cu}$ contents in spring samples from Locality II was $r=0.9272$, i.e., the correlation between the observed elements contents was very tight. Between the $\mathrm{Zn}$ and $\mathrm{Cd}$ contents $(\mathrm{r}=-0.5375)$, and between the $\mathrm{Zn}$ and $\mathrm{Pb}$ contents $(r=0.5655)$ the correlation was significant. In contrast, the correlations between the contents of the other examined elements were only mild.

Based on the calculated correlation coefficients, we argued that between the $\mathrm{Cu}$ and $\mathrm{Cd}$ contents $(\mathrm{r}=0.5262)$ and between the $\mathrm{Cd}$ and $\mathrm{Pb}$ contents $(\mathrm{r}=-0.5971)$ in autumn samples from Locality II, there were significant correlations. The correlations between the contents of the other analyzed elements from this locality were none or only mild.

The value of the correlation coefficient between the $\mathrm{Zn}$ and $\mathrm{Cu}$ contents in the soil in spring samples from Locality III was $r=0.8704$, which indicates a high correlation. Table 5 shows that, between the $\mathrm{Zn}$ and $\mathrm{Pb}$ contents, there was a significant degree of correlation $(r=0.5653)$. The correlations between the contents of the other analyzed elements were only mild or even non-existent.

Lastly, based on the calculated values of correlation coefficients summarized in Table 5, it can be stated that between the $\mathrm{Zn}$ and $\mathrm{Cu}$ contents $(\mathrm{r}=0.8853)$ and between the $\mathrm{Cd}$ and $\mathrm{Pb}$ contents $(\mathrm{r}=-0.7186)$ in autumn samples from Locality III, there was a high degree of correlation. The value of the correlation coefficient between the $\mathrm{Cu}$ and $\mathrm{Cd}$ contents was $\mathrm{r}=-0.5501$. In contrast, the correlation coefficient between the $\mathrm{Cu}$ and $\mathrm{Pb}$ contents was $r=0.5829$, which indicates a significant degree of correlation. Based on the calculated correlation coefficients shown in Table 5, the correlations between the contents of $\mathrm{Zn}$ and $\mathrm{Cd} / \mathrm{Pb}$ were only mild.

\subsection{Influence of Selected Factors ( $p H$ and TOC) on the Mobility of Heavy Metals in Soil}

The obtained results (Tables 6-10) were related to the influence of soil factors ( $\mathrm{pH}$ and TOC) on the mobility of heavy metals at Localities I-III expressed through their correlations.

\subsection{1. $\mathrm{pH}$ Values in Soil Units of Localities I-III}

The average $\mathrm{pH}$ values of active and exchangeable soil reaction in the observed periods at Locality I ranged from neutral to acidic, at Locality II from neutral to mildly acidic, and at Locality III from mildly alkaline to neutral. The average values of active and exchangeable soil reaction in the observed periods are summarized in Table 6a,b.

\subsubsection{Correlation Analysis between $\mathrm{pH}$ Values and Heavy Metal Contents}

In our study, we analyzed the correlations between the concentrations of the heavy metals and the $\mathrm{pH}\left(\mathrm{H}_{2} \mathrm{O}\right)$ values at the observed localities (Localities I-III) (Table 7).

The correlation coefficients were calculated between all the recorded $\mathrm{pH}$ values and the heavy metals concentrations in two seasons (spring and autumn) in 2017-2019. The rank correlation coefficient was also applied to calculate the degree of interdependence between the observed variables [81].

As Table 7 shows, the value of the correlation coefficient between the $\mathrm{Zn}$ content and $\mathrm{pH}$ (spring) at Locality I was $\mathrm{r}=0.5594$, which means that there was a significant degree of correlation between the observed variables. As indicated by the value of the correlation coefficient between the $\mathrm{Cd}$ content and $\mathrm{pH}$ (spring) $(\mathrm{r}=-0.7265)$, there was a high negative correlation between these variables. The values of correlation coefficients between the contents of other heavy metals in soil samples and the $\mathrm{pH}\left(\mathrm{H}_{2} \mathrm{O}\right)$ values indicate that the degree of correlation was none or only mild between these variables.

Based on the calculated correlation coefficients, we argued that between the $\mathrm{Zn}$ content and $\mathrm{pH}$ (spring) $(\mathrm{r}=0.6440)$, between the $\mathrm{Cu}$ content and $\mathrm{pH}$ (spring $)(\mathrm{r}=0.5558)$, and between the $\mathrm{Cu}$ content and $\mathrm{pH}($ autumn $)(\mathrm{r}=-0.6894)$ at Locality II there were significant correlations. A high correlation degree $(\mathrm{r}=0.8420)$ was observed between the $\mathrm{Pb}$ content and $\mathrm{pH}$ (spring). The values of correlation coefficients between the contents of 
the other heavy metals and $\mathrm{pH}\left(\mathrm{H}_{2} \mathrm{O}\right)$ suggest zero or only mild interdependence between the observed variables.

Table 6. (a) $\mathrm{pH}\left(\mathrm{H}_{2} \mathrm{O}\right)$ values (spring, autumn 2017-2019). (b) $\mathrm{pH}(\mathrm{KCl})$ values (spring, autumn 2017-2019).

\begin{tabular}{|c|c|c|c|c|c|c|c|c|c|c|c|c|}
\hline \multicolumn{13}{|c|}{ (a) } \\
\hline Localities & \multicolumn{4}{|c|}{2017} & \multicolumn{4}{|c|}{2018} & \multicolumn{4}{|c|}{2019} \\
\hline Spring & Ave \pm SD & Min & Max & Median & Ave \pm SD & Min & $\operatorname{Max}$ & Median & Ave \pm SD & Min & $\operatorname{Max}$ & Median \\
\hline Locality I & $6.41 \pm 0.11$ & 6.26 & 6.60 & 6.40 & $6.21 \pm 0.17$ & 5.96 & 6.46 & 6.15 & $6.78 \pm 0.05$ & 6.71 & 6.86 & 6.76 \\
\hline Locality II & $7.09 \pm 0.05$ & 7.00 & 7.15 & 7.08 & $7.38 \pm 0.05$ & 7.32 & 7.45 & 7.37 & $7.64 \pm 0.05$ & 7.56 & 7.71 & 7.63 \\
\hline Locality III & $7.22 \pm 0.07$ & 7.12 & 7.31 & 7.22 & $7.56 \pm 0.08$ & 7.46 & 7.66 & 7.52 & $7.55 \pm 0.09$ & 7.46 & 7.70 & 7.50 \\
\hline Autumn & Ave \pm SD & Min & Max & Median & Ave \pm SD & Min & Max & Median & Ave \pm SD & Min & Max & Median \\
\hline Locality I & $6.40 \pm 0.10$ & 6.24 & 6.53 & 6.41 & $6.84 \pm 0.09$ & 6.75 & 7.01 & 6.81 & $7.03 \pm 0.06$ & 6.95 & 7.10 & 7.03 \\
\hline Locality II & $6.59 \pm 0.17$ & 6.41 & 6.80 & 6.52 & $7.76 \pm 0.05$ & 7.71 & 7.84 & 7.77 & $7.18 \pm 0.24$ & 6.76 & 7.43 & 7.31 \\
\hline Locality III & $6.81 \pm 0.29$ & 6.41 & 7.15 & 6.83 & $7.59 \pm 0.14$ & 7.40 & 7.85 & 7.49 & $7.65 \pm 0.09$ & 7.50 & 7.76 & 7.66 \\
\hline \multicolumn{13}{|c|}{ (b) } \\
\hline Localities & \multicolumn{4}{|c|}{2017} & \multicolumn{4}{|c|}{2018} & \multicolumn{4}{|c|}{2019} \\
\hline Spring & Ave \pm SD & Min & Max & Median & Ave \pm SD & Min & Max & Median & Ave \pm SD & Min & Max & Median \\
\hline Locality I & $6.06 \pm 0.07$ & 5.95 & 6.15 & 6.08 & $5.15 \pm 0.28$ & 4.81 & 5.52 & 5.05 & $5.29 \pm 0.31$ & 4.80 & 5.65 & 5.31 \\
\hline Locality II & $6.64 \pm 0.23$ & 6.25 & 6.96 & 6.63 & $6.33 \pm 0.18$ & 6.11 & 6.55 & 6.30 & $6.35 \pm 0.33$ & 6.08 & 6.92 & 6.11 \\
\hline Locality III & $6.80 \pm 0.13$ & 6.61 & 6.95 & 6.82 & $6.71 \pm 0.19$ & 6.42 & 6.89 & 6.82 & $6.65 \pm 0.07$ & 6.55 & 6.72 & 6.67 \\
\hline Autumn & Ave \pm SD & Min & Max & Median & Ave \pm SD & Min & $\operatorname{Max}$ & Median & Ave \pm SD & Min & Max & Median \\
\hline Locality I & $5.09 \pm 0.13$ & 4.89 & 5.24 & 5.05 & $5.59 \pm 0.27$ & 5.24 & 5.95 & 5.57 & $5.57 \pm 0.26$ & 5.14 & 5.81 & 5.73 \\
\hline Locality II & $5.49 \pm 0.05$ & 5.43 & 5.56 & 5.47 & $6.48 \pm 0.30$ & 6.10 & 6.83 & 6.47 & $6.37 \pm 0.19$ & 6.06 & 6.61 & 6.34 \\
\hline Locality III & $6.05 \pm 0.10$ & 5.87 & 6.14 & 6.11 & $6.76 \pm 0.08$ & 6.64 & 6.87 & 6.76 & $6.64 \pm 0.08$ & 6.53 & 6.76 & 6.62 \\
\hline
\end{tabular}

Table 7. Correlation coefficients between concentrations of heavy metals and $\mathrm{p}\left(\mathrm{H}_{2} \mathrm{O}\right)$ values at Localities I-III in 2017-2019 (spring and autumn).

\begin{tabular}{ccccccc}
\hline Metal Contaminant & \multicolumn{2}{c}{ Locality I } & \multicolumn{2}{c}{ Locality II } & \multicolumn{2}{c}{ Locality III } \\
\hline $\mathrm{pH}$ & spring & autumn & spring & autumn & spring & autumn \\
$\mathrm{Cd}$ & 0.3915 & -0.7265 & -0.3368 & -0.3103 & -0.0481 & -0.6234 \\
$\mathrm{Cu}$ & -0.2023 & -0.0859 & 0.5558 & -0.6894 & 0.2543 & -0.0484 \\
$\mathrm{~Pb}$ & -0.0744 & 0.2617 & 0.8420 & 0.3324 & 0.6637 & 0.5633 \\
$\mathrm{Zn}$ & 0.5594 & -0.2750 & 0.6440 & 0.1895 & 0.2272 & -0.2466 \\
\hline
\end{tabular}

Table 8. Average TOC content (\%) at Localities I-III in 2017-2019 (spring and autumn).

\begin{tabular}{|c|c|c|c|c|c|c|c|c|c|}
\hline \multirow{3}{*}{$\begin{array}{c}\text { TOC Content } \\
\text { Years }\end{array}$} & \multicolumn{9}{|c|}{ Localities } \\
\hline & \multicolumn{3}{|c|}{ I } & \multicolumn{3}{|c|}{ II } & \multicolumn{3}{|c|}{ III } \\
\hline & 2017 & 2018 & 2019 & 2017 & 2018 & 2019 & 2017 & 2018 & 2019 \\
\hline TOC spring & 1.32 & 0.87 & 0.88 & 1.03 & 1.34 & 0.90 & 1.23 & 1.60 & 1.43 \\
\hline TOC spring Ave. & & 1.02 & & & 1.09 & & & 1.42 & \\
\hline TOC autumn & 1.04 & 1.10 & 1.18 & 1.08 & 0.95 & 1.31 & 1.24 & 1.46 & 1.22 \\
\hline TOC autumn Ave. & & 1.11 & & & 1.22 & & & 1.31 & \\
\hline
\end{tabular}

Note: Ave. = Average.

As indicated by the results in Table 7 , there was a significant interdependence between the $\mathrm{Pb}$ content and $\mathrm{pH}$ (spring) $(\mathrm{r}=0.6637)$, between the $\mathrm{Cd}$ content and $\mathrm{pH}$ (autumn) $(\mathrm{r}=-0.6234)$, and between the $\mathrm{Pb}$ content and $\mathrm{pH}($ autumn $)(\mathrm{r}=0.5633)$ at Locality III. There was no interdependence in the other cases of heavy metal contents and values of $\mathrm{pH}\left(\mathrm{H}_{2} \mathrm{O}\right)$. 
Table 9. Mann-Whitney test results (spring-autumn).

\begin{tabular}{ccc}
\hline \multirow{2}{*}{ Monitor Character } & \multicolumn{3}{c}{ Spring-Autumn } \\
\cline { 2 - 3 } & $\mathbf{Z}$ & $p$-Value \\
\hline $\mathrm{pH}\left(\mathrm{H}_{2} \mathrm{O}\right)$ & -4.238 & $0.000^{1}$ \\
$\mathrm{pH}(\mathrm{KCl})$ & -1.397 & 0.162 \\
$\mathrm{TOC}$ & 0.437 & 0.662 \\
\hline
\end{tabular}

${ }^{1}$ Statistically different values.

Table 10. Multiple comparison of $\mathrm{pH}$ values $\left(\mathrm{pH}\left(\mathrm{H}_{2} \mathrm{O}\right)\right.$ and $\left.\mathrm{pH}(\mathrm{KCl})\right)$ spring period.

\begin{tabular}{ccccccc}
\hline \multirow{2}{*}{ Localities } & \multicolumn{3}{c}{$\mathbf{p H}\left(\mathbf{H}_{2} \mathbf{O}\right)$} & \multicolumn{3}{c}{$\mathbf{p H}(\mathrm{KCl})$} \\
\cline { 2 - 7 } & Locality I & Locality II & Locality III & Locality I & Locality II & Locality III \\
\hline Locality I & - & 0.2880 & $0.0003^{1}$ & - & 0.1576 & $0.0010^{1}$ \\
Locality II & - & 1.0000 & - & 1.0000 \\
Locality III & & & - & - \\
\hline
\end{tabular}

${ }^{1}$ Statistically different values.

\subsubsection{Analysis of Total Organic Carbon Content}

In the arable lands (Localities I-III) where inorganic fertilizers were used before sowing, regarding the crops' requirements and ploughing in the residuals after harvest, the average values of total organic carbon (henceforth TOC) at Localities I and II were low. In contrast, at Locality III, the average TOC was medium (Table 8).

Based on the obtained data, the average TOC content in 2017-2019 was as follows: at Locality I the TOC decreased from medium to low; at Locality II the TOC content increased from low to medium; and at Locality III the TOC remained medium.

Analysis of Differences between Seasons in $\mathrm{pH}\left(\mathrm{H}_{2} \mathrm{O}\right), \mathrm{pH}(\mathrm{KCl})$ Values and TOC Content

As Table 8 shows, the average TOC values at the three localities vary throughout seasons. Our objective was to determine if the recorded data regarding $\mathrm{pH}\left(\mathrm{H}_{2} \mathrm{O}\right), \mathrm{pH}(\mathrm{KCl})$, and TOC in two seasons (spring and autumn) are statistically significantly different.

The results in Table 9 suggest that the recorded $\mathrm{pH}\left(\mathrm{H}_{2} \mathrm{O}\right)$ values differ significantly in two seasons; in other words, two seasons differ significantly in $\mathrm{pH}\left(\mathrm{H}_{2} \mathrm{O}\right)$ values. The differences between the values of the other examined variables $(\mathrm{pH}(\mathrm{KCI})$ and $\mathrm{TOC})$ in two seasons are not statistically significant.

Analysis of Differences between Localities I-III in $\mathrm{pH}\left(\mathrm{H}_{2} \mathrm{O}\right)$ and $\mathrm{pH}(\mathrm{KCl})$ Values and TOC Content in Soil

As the results shown in Tables 6-9 indicate, between Localities I-III in the examined variables-recorded values of $\mathrm{pH}\left(\mathrm{H}_{2} \mathrm{O}\right), \mathrm{pH}(\mathrm{KCl})$, and TOC in the soil in two seasons (spring and autumn) - there are some differences. The multiple comparison results ( $p$-values) for springs 2017-2019 are summarized in Table 10.

Based on the results shown in Table 10, it can be seen that in the springs of the examined years, Localities I and III differed significantly in the recorded $\mathrm{pH}\left(\mathrm{H}_{2} \mathrm{O}\right)$ values. In the studied years' springs, the localities' average $\mathrm{pH}$ values were as follows: at Locality I $\mathrm{pH}=6.47$; at Locality II $\mathrm{pH}=7.37$; and at Locality III pH = 7.44 (Table 6a).

An analogous procedure was performed to verify the statistical significance of the differences between Localities I-III in recorded $\mathrm{pH}(\mathrm{KCI})$ values in the soil samples (Table 10). The statistical analysis proved that in the springs from 2017-2019, Locality III differed significantly from Locality I in $\mathrm{pH}(\mathrm{KCI})$ values. The average $\mathrm{pH}(\mathrm{KCI})$ values in the springs from 2017-2019 at the three localities were as follows: at Locality $\mathrm{I} \mathrm{pH}(\mathrm{KCl})=5.50$; at Locality II $\mathrm{pH}(\mathrm{KCl})=6.44$; and at Locality III $\mathrm{pH}(\mathrm{KCl})=6.72$ (Table 6b).

The same statistical methods were applied to test the statistical significance of the differences in the TOC's variable between the localities. Based on the Kruskal-Wallis test results, the TOC in the soil samples from the three examined localities in the springs from 2017-2019 are not significantly different. 
Lastly, the Kruskal-Wallis test was applied to verify if the three localities (Localities I-III) differ significantly in three variables $\left(\mathrm{pH}\left(\mathrm{H}_{2} \mathrm{O}\right), \mathrm{pH}(\mathrm{KCl})\right.$, and $\mathrm{TOC}$ values) in the autumns from 2017-2019. Based on the results summarized in Table 11, it can be seen that Localities I and III differed significantly in the recorded values of $\mathrm{pH}\left(\mathrm{H}_{2} \mathrm{O}\right)$.

Table 11. Multiple comparison of $\mathrm{pH}$ values $\left(\mathrm{pH}\left(\mathrm{H}_{2} \mathrm{O}\right.\right.$ and $\left.\mathrm{pH}(\mathrm{KCl})\right)$ autumn period.

\begin{tabular}{ccccccc}
\hline \multirow{2}{*}{ Localities } & \multicolumn{3}{c}{$\mathbf{p H}\left(\mathrm{H}_{2} \mathrm{O}\right)$} & \multicolumn{3}{c}{$\mathbf{p H}(\mathrm{KCl})$} \\
\cline { 2 - 7 } & Locality I & Locality II & Locality III & Locality I & Locality II & Locality III \\
\hline Locality I & - & 1.0000 & $0.0200^{1}$ & - & 0.4844 & $0.0080^{1}$ \\
Locality II & - & 1.0000 & - & 1.0000 \\
Locality III & & & - & - & - \\
\hline
\end{tabular}

${ }^{1}$ Statistically different values.

Therefore, $\mathrm{pH}\left(\mathrm{H}_{2} \mathrm{O}\right)$ values recorded in the soil samples taken from the examined localities in the autumns from 2017-2019 are significantly different. The average $\mathrm{pH}\left(\mathrm{H}_{2} \mathrm{O}\right)$ values in the localities during the periods in question were as follows: at Locality I $\mathrm{pH}\left(\mathrm{H}_{2} \mathrm{O}\right)=6.76$; at Locality II $\mathrm{pH}\left(\mathrm{H}_{2} \mathrm{O}\right)=7.11$; and at Locality III $\mathrm{pH}\left(\mathrm{H}_{2} \mathrm{O}\right)=7.35$ (Table 6a).

As the results in Table 11 suggest, in the autumns from 2017-2019, Locality III differed significantly from Locality I in $\mathrm{pH}(\mathrm{KCI})$ values recorded in the soil samples. In other words, the recorded $\mathrm{pH}(\mathrm{KCI})$ values of the soil samples taken from Localities I and III in the autumns from 2017-2019 are significantly different. The average $\mathrm{pH}(\mathrm{KCI})$ values in the autumns from 2017-2019 at the three localities are as follows: at Locality I $\mathrm{pH}(\mathrm{KCl})=5.4$; at Locality II $\mathrm{pH}(\mathrm{KCl})=5.95$; and at Locality III $\mathrm{pH}(\mathrm{KCl})=6.48$ (Table 6b).

The same procedure was applied to test the statistical significance of the differences between the examined localities in the variable TOC recorded in the soil samples. The TOC values recorded in the soil samples taken from the localities in autumns 2017-2019 do not differ significantly.

It should be noted that the concentrations of the examined heavy metals $(\mathrm{Cd}, \mathrm{Cu}, \mathrm{Pb}$, and $\mathrm{Zn}$ ) in soil samples were evaluated in terms of the decree currently in force by the method of dissolution in aqua regia. The evaluation of the relation between the agricultural land and plants was also performed by means of $\mathrm{NH}_{4} \mathrm{NO}_{3}\left(\mathrm{c}\left(\mathrm{NH}_{4} \mathrm{NO}_{3}\right)=1 \mathrm{~mol} \mathrm{dm}{ }^{-3}\right)$ leachate to make the analysis more complex (Table 12) [76].

Table 12. Average content of heavy metals in soil samples (in $1 \mathrm{~mol} \cdot \mathrm{dm}^{-3}$ leachate $\mathrm{NH}_{4} \mathrm{NO}_{3}$ ) in 2017-2019.

\begin{tabular}{cccccc}
\hline \multirow{2}{*}{ Localities } & Seasons & $\mathbf{C d}^{\mathbf{1}}$ & $\mathbf{C u}^{\mathbf{1}}$ & $\mathbf{P b}^{\mathbf{1}}$ & $\mathbf{Z n}^{\mathbf{1}}$ \\
\cline { 3 - 6 } & & $\left.\mathbf{( m g} \cdot \mathbf{k g}^{\mathbf{- 1}}\right)$ & $\left.\mathbf{( m g} \cdot \mathbf{k g}^{-\mathbf{1}}\right)$ & $\mathbf{( m g} \cdot \mathbf{k g} \mathbf{- 1}^{\mathbf{1}}$ & $\mathbf{( m g} \cdot \mathbf{k g} \mathbf{- 1}^{\mathbf{1}}$ \\
\hline \multirow{2}{*}{ Locality I } & Spring & 0.08 & 0.64 & 0.25 & 1.28 \\
& Autumn & 0.06 & 0.63 & 0.71 & 1.25 \\
\hline \multirow{2}{*}{ Locality II } & Spring & 0.04 & 0.67 & 0.26 & 1.34 \\
& Autumn & 0.08 & 0.87 & 0.99 & 1.22 \\
\hline \multirow{2}{*}{ Locality III } & Spring & 0.04 & 0.66 & 0.35 & 1.32 \\
& Autumn & 0.07 & 0.67 & 1.05 & 1.33 \\
\hline
\end{tabular}

${ }^{1}$ The limit value for heavy metals in relation to agricultural land and plant-critical values (in $\mathrm{mg} \mathrm{kg}^{-1} \mathrm{dry}$ matter in leachate $1 \mathrm{~mol} \cdot \mathrm{dm}^{-3} \mathrm{NH}_{4} \mathrm{NO}_{3}$ ) for $\mathrm{Cd}=0.1 \mathrm{mg} \mathrm{kg}{ }^{-1}, \mathrm{Cu}=1.0 \mathrm{mg} \mathrm{kg}^{-1}, \mathrm{~Pb}=0.1 \mathrm{mg} \mathrm{kg} \mathrm{kg}^{-1}$, and $\mathrm{Zn}=2.0 \mathrm{mg} \mathrm{kg}^{-1}[76]$.

The comparison of heavy metal contents $(\mathrm{Cd}, \mathrm{Cu}, \mathrm{Pb}$, and $\mathrm{Zn})$ in soil samples obtained using dissolution in aqua regia exceeded the limit value of $\mathrm{Cd}\left(0.70 \mathrm{mg} \cdot \mathrm{kg}^{-1}\right)$ in all three localities throughout the examined periods (spring and autumn, 2017-2019) (Tables 2-4). In $\mathrm{NH}_{4} \mathrm{NO}_{3}$ leach, $\mathrm{Cd}$ contents $\left(0.10 \mathrm{mg} \cdot \mathrm{kg}^{-1}\right)$ did not exceed the critical value in any of the three localities (Table 12). The Pb contents (limit value $\mathrm{Pb}=70 \mathrm{mg} \cdot \mathrm{kg}^{-1}$ ) found in the soil samples by means of aqua regia dissolution in the springs from 2017-2019 were exceeded in Localities II and III in 2018 (Tables 2-4). Although in the autumn samples, the 
average $\mathrm{Pb}$ contents obtained with aqua regia dissolution did not exceed the limit values, in autumn samples taken from some depths, the concentration of $\mathrm{Pb}$ did exceed the limit values. In $\mathrm{NH}_{4} \mathrm{NO}_{3}$ leach, $\mathrm{Pb}$ contents $\left(0.1 \mathrm{mg} \cdot \mathrm{kg}^{-1}\right)$ exceeded all three localities' critical values (Table 12). Particular attention should be paid to $\mathrm{Pb}$ due to its determinative role in evaluating soil contamination and potential environmental hazard. Furthermore, $\mathrm{Pb}$ is not an essential element, it is more toxic to life forms, and can be easily absorbed by organisms.

Based on the results of the soil analyses done using aqua regia dissolution (Tables 2-4), we can conclude that the limit values of copper $\left(60 \mathrm{mg} \cdot \mathrm{kg}^{-1}\right)$ and zinc $\left(150 \mathrm{mg} \cdot \mathrm{kg}^{-1}\right)$ in the examined arable lands did not exceed limits in any of the studied periods (spring and autumn) 2017-2019. In $\mathrm{NH}_{4} \mathrm{NO}_{3}$ leach, $\mathrm{Cu}$ and $\mathrm{Zn}$ contents did not exceed the critical values $\left(\mathrm{Cu}=1.0 \mathrm{mg} \cdot \mathrm{kg}^{-1}, \mathrm{Zn}=2.0 \mathrm{mg} \cdot \mathrm{kg}^{-1}\right)$ (Table 12). The comparison of results shows that the excessive concentrations of the given elements concerning the limit and critical values are identical. Soil samples analyzed in $\mathrm{NH}_{4} \mathrm{NO}_{3}$ leach, and their comparison with critical values, are essential in evaluating agricultural land and plants' relation. Industrialization and urbanization increase soil contamination, resulting in harmful environmental safety effects, including plants.

As Table 13 suggests, the average contents of $\mathrm{Zn}, \mathrm{Cd}$, and $\mathrm{Cu}$ in the examined years 2017-2019 did not exceed the critical values [75] in the studied localities where analyzed plant material was obtained. An exception was the values of $\mathrm{Pb}$, which exceeded the allowed critical value at all three localities throughout the examined years. The heavy metals were analyzed in various plant parts of winter wheat (root, stalk, leaf, and kernel). The contents of heavy metals in the plant parts are summarized in Table 13.

Table 13. Average contents of heavy metals in plant samples (dry material in $\mathrm{mg} \mathrm{kg}^{-1}$ ) in 2017-2019.

\begin{tabular}{|c|c|c|c|c|c|}
\hline Localities & Part of Plant & Cd & $\mathrm{Cu}$ & $\mathrm{Pb}$ & $\mathrm{Zn}$ \\
\hline \multirow{4}{*}{ Locality I } & root & 0.30 & 15.50 & 2.40 & 61.95 \\
\hline & stalk & 0.00 & 2.00 & 0.60 & 8.14 \\
\hline & leaf & 0.00 & 2.90 & 1.70 & 3.54 \\
\hline & grain & 0.00 & 4.40 & 0.00 & 25.47 \\
\hline \multirow{4}{*}{ Locality II } & root & 0.30 & 22.10 & 2.60 & 85.41 \\
\hline & stalk & 0.00 & 1.80 & 0.75 & 5.65 \\
\hline & leaf & 0.00 & 3.60 & 1.80 & 4.00 \\
\hline & grain & 0.00 & 4.10 & 0.00 & 18.38 \\
\hline \multirow{4}{*}{ Locality III } & root & 0.20 & 18.00 & 2.90 & 44.40 \\
\hline & stalk & 0.00 & 7.20 & 0.85 & 13.66 \\
\hline & leaf & 0.00 & 6.40 & 1.85 & 16.38 \\
\hline & grain & 0.00 & 4.20 & 0.00 & 21.98 \\
\hline
\end{tabular}

An increase in heavy metal content in plants may cause their hygienic defects. According to the Decree of the Ministry of Agriculture and Rural Development and the Ministry of Health of the Slovak Republic No. 14300/2007-OL, through which the title of the Foodstuff Code of the Slovak Republic is issued, stating the limits for contaminants in foodstuff, the maximum permissible Cd content in kernels (MAA = Maximum Allowable Amount; MAA Cd $=0.2 \mathrm{mg} \mathrm{kg}^{-1}$ for wheat) was not exceeded in the analyzed parts of plants grown in Localities I-III $[82,83]$. Nor was the maximum permissible $\mathrm{Pb}$ content in kernels (MAA $\mathrm{Pb}=0.2 \mathrm{mg} \mathrm{kg}^{-1}$ for grain) exceeded from the examined localities.

A rather complex issue is the bioavailability of elements in terms of the interactions between agricultural land and plants. The evaluation of bioaccumulation of elements from the geological environment in the food chain is based on the analysis of the translocation of potentially toxic elements from soil to specific, locally grown plant products, e.g., cereals [84]. The relative bioavailability is expressed through the bioaccumulation coefficient (BAC). Its calculation is based on the element's content in a plant in proportion to the element's total content in the soil. The bioaccumulation measure of potentially toxic elements in plants is evaluated based on BAC values in terms of the classification suggested 
by Selinus et al. [85]. The average BAC values (BAC = the element's content in a plant/the element's total content in the soil) in the examined years 2017-2019 are summarized in Table 14.

Table 14. Bioaccumulation coefficient for potential heavy metals.

\begin{tabular}{cccccc}
\hline \multirow{2}{*}{ Arable Soils } & Seasons & \multicolumn{4}{c}{ Bioaccumulation Coefficient } \\
\cline { 2 - 6 } & & $\mathbf{C d}$ & $\mathbf{C u}$ & $\mathbf{P b}$ & $\mathbf{Z n}$ \\
\hline \multirow{2}{*}{ Locality I } & Spring & 4.67 & 0.73 & 0.09 & 0.63 \\
& Autumn & 0.00 & 0.79 & 0.08 & 0.53 \\
\hline \multirow{2}{*}{ Locality II } & Spring & 6.00 & 0.63 & 0.06 & 0.53 \\
& Autumn & 3.33 & 0.66 & 0.07 & 0.56 \\
\hline \multirow{2}{*}{ Locality III } & Spring & 4.00 & 0.56 & 0.07 & 0.61 \\
& Autumn & 4.00 & 0.59 & 0.09 & 0.89 \\
\hline
\end{tabular}

\section{Discussion}

Based on the researched results and analyses of the measured values of heavy metals in arable soils (Tables 2-4) at the monitored localities in the surface layer, we conclude that the content values of $\mathrm{Cu}$ and $\mathrm{Zn}$ did not exceed the limit values in any of the monitored periods. Zn's average contents did not reach even $50 \%$ of the permitted limit value in arable soils. When comparing these results with the study of Wang et al. [86], we conclude that these two heavy metals $(\mathrm{Cu}$ and $\mathrm{Zn}$ ) are not identical in this study. The results of Wang et al. [86] accord with our findings-they exceeded the limit content value of $\mathrm{Pb}$ in the surface layer in 2019 at Localities II -III. They are also identical with the exceeded Cd limit values in the surface layer in all monitored arable soils (except autumn 2019 at Locality I). Our results also confirm the conclusions of the authors Yuanan et al. [87]; in general, the heavy metals in the soil's surface layers indicate the impact of human activity. Soil contamination by $\mathrm{Cd}$ can be caused by, amongst other reasons, the use of large amounts of inorganic fertilizers, mainly phosphorus fertilizers [88-91], and also agrochemicals [44], which were also used in the localities we monitored.

Our results confirm the findings of Rodríguez-Bocanegra et al. [11], who observed in their study that contents of $\mathrm{Cu}, \mathrm{Pb}$, and $\mathrm{Zn}$ are higher in the topsoil than in the subsoil. We think this was caused by natural geological subsoil, mineralogical and geochemical character, or groundwater. Parent rocks (e.g., granite and sandstone) also affect soil contamination, especially $\mathrm{Cd}, \mathrm{Cu}$, and $\mathrm{Zn}$. Similar conclusions were reached by Feng et al. [92].

We also found differences in the content values of $\mathrm{Pb}$. When compared with our results, we agree with the study by Roca et al. [93] that limited mobility and strong incorporation of $\mathrm{Pb}$ in organic matter leads to bioaccumulation of this element in horizons of surface soil rich in humus.

By running the analyses, we found out that soil samples were contaminated most by $\mathrm{Cd}$. Simultaneously, low to medium contamination of heavy metals was recorded with $\mathrm{Cu}, \mathrm{Pb}$, and $\mathrm{Zn}$ (except the content values of $\mathrm{Pb}$ in selected localities in the springs from 2017-2019). This study agrees with the findings of Li et al. [94]. The source of even low or medium contamination of $\mathrm{Cu}, \mathrm{Pb}$, and $\mathrm{Zn}$ could be exhaust fumes from transport (road no. 65 is near Locality III). On the other hand, exceeding the allowed Cd limit values could have been affected by fertilization and industrial emissions. This statement correlates with Li et al. [94] and Feng et al. [92]. Our results also confirm the theory of Ye et al. [95], that the spatiotemporal dynamics of heavy metals $(\mathrm{Cd}, \mathrm{Cu}, \mathrm{Zn}$, and $\mathrm{Pb})$ may be due to the physical and chemical properties of the soil.

In soil samples from Localities I-III, which we analyzed, we were interested in how heavy metal content values changed after the application of fertilizers within three years. During the observed period, the input of heavy metals was as follows: $\mathrm{Pb}>\mathrm{Cu}=\mathrm{Zn}>\mathrm{Cd}$ (Localities I-II) and $\mathrm{Pb}>\mathrm{Cu}>\mathrm{Zn}>\mathrm{Cd}$ (Locality III). Our results are similar to those measured by Belon et al. [96] and $\mathrm{Hu}$ et al. [97]. We differ between these two heavy metals: 
$\mathrm{Pb}$ and $\mathrm{Zn}$. In the analyses of the content values of $\mathrm{Cd}$ and $\mathrm{Cu}$ in arable soil, the average content of $\mathrm{Cd}$ had a decreasing trend for the whole monitored period. The content values of $\mathrm{Cu}$ increased from 2017 to 2018 and decreased from 2018 to 2019. When comparing these results with the study of Zhao et al. [98], we conclude that the average content values of $\mathrm{Cd}$ are not identical to this study. The trends observed differ from those found in arable land by Shao et al. [99] for the last 15 years. The reason for this difference may be reduced inputs from anthropogenic sources (reduced application of fungicide-based copper). From the results obtained from the study by Hu et al. [97], heavy metals in fertilizers represent an environmental risk.

Based on the correlation coefficients of the calculated values of the contents of the monitored heavy metals in the soil, we reached the following results. At Locality II and Locality III in the autumn periods 2017-2019, the metals Cu and Cd were negatively correlated with each other (Table 5), i.e., with increasing $\mathrm{Cu}$ content values, the $\mathrm{Cd}$ content decreased and vice versa. This is consistent with the finding made by Huang et al. [100]. In contrast, Demková et al. [101], in their study, noted that all studied heavy metals were significantly positively correlated with each other, except for the relationship between the total $\mathrm{Cu}$ and $\mathrm{Cd}$ content.

If we consider the $\mathrm{pH}\left(\mathrm{H}_{2} \mathrm{O}\right)$ values (Table 7 ), which affect the mobility of heavy metals, based on the calculated correlation coefficients in the autumn period with increasing $\mathrm{pH}\left(\mathrm{H}_{2} \mathrm{O}\right), \mathrm{Cu}$ content at Locality II and Cd content at Locality III were decreased. Huang et al. [100] reached similar results. Our study showed that, due to the experimental characteristic and TOC contents in the autumn period in the observed years, TOC contents in soil samples taken from the monitored localities are not statistically significantly different. Instead, we agree with Li et al. [94], who concluded that the soil's physicochemical properties mainly influenced the soil's contamination.

The correlation coefficient between the heavy metal $\mathrm{Zn}$ content and $\mathrm{Cu}$ and $\mathrm{Pb}$ content were evident in all three arable soils in the spring periods of 2017-2019 (Table 5). A similar result was reached by Demková et al. [101]. If there is a significant correlation between the elements, it is that they originate from the same source. Chai et al. [102] reports that the positive correlations between $\mathrm{Cu}, \mathrm{Pb}$, and $\mathrm{Zn}$ may reflect their soil's geochemical affinities.

It was also confirmed, based on the calculated values of the correlation coefficients, that the high degree of bonding was between the contents of the metals $\mathrm{Zn}$ and $\mathrm{Cu}$ at Locality I (autumn) and Locality III (spring and autumn). At Locality II, a very close correlation was observed between the contents of metals $\mathrm{Zn}$ and $\mathrm{Cu}$. A high degree of correlation was also confirmed between the contents of metals $\mathrm{Cd}$ and $\mathrm{Pb}$ at Locality III (autumn) and between the contents of metals $\mathrm{Cu}$ and $\mathrm{Pb}$ at Locality I (spring). Lv and Wang [103] obtained similar results. The correlation of Cd with other heavy metals may have a mixed source (e.g., lithogenic and anthropogenic) or different geochemical properties from other heavy metals in the soil, as reported by Chai et al. [102]. The authors Yuanan et al. [87] stated that, in general, high values of the correlation coefficients between the contents of the heavy metals are likely to contribute to the same or closely related sources. The contents of the heavy metals $\mathrm{Cu}, \mathrm{Pb}$, and $\mathrm{Zn}$, can be interconnected and are probably partially influenced by biological factors, the content of organic substances in the soil, and/or pollution [104].

We also used the correlation coefficient to measure statistical dependence between $\mathrm{pH}$ values (spring and autumn) and heavy metal content. We chose this particular method per Zhao et al. [105], who stated in their study that correlation analysis is an effective method for revealing the relationship between heavy metals in soil and soil properties. Based on the calculated values of the correlation coefficients, we confirmed that the $\mathrm{Zn}$ content also increases at Locality I with the increase in the $\mathrm{pH}$ (spring) value. The $\mathrm{Zn}$ content has a much lower affinity to the soil's organic matters so that the $\mathrm{pH}$ soil instead drives the total concentration of the $\mathrm{Zn}$ content and the $\mathrm{Zn}^{2+}$ activity in the soil solution [106]. In the case of $\mathrm{Cd}$, by increasing $\mathrm{pH}$ (autumn), the $\mathrm{Cd}$ value decreases (i.e., $\mathrm{Cd}$ mobility is more prominent in an acidic environment). At Locality II, $\mathrm{Cu}$ and $\mathrm{Zn}$ contents had higher 
concentrations in neutral soil $\mathrm{pH}$. The concentration of $\mathrm{Cu}$ and $\mathrm{Zn}$ in an acidic environment is higher than in the alkaline state [107]. We calculated a statistically significant correlation between the $\mathrm{Cu}$ content and $\mathrm{pH}$ (spring and autumn) values. In the spring period, the $\mathrm{Cu}$ content increased with increasing $\mathrm{pH}$ values (Table 6a) and in the autumn period vice versa. $\mathrm{Cu}$ adsorption in soil has a stronger $\mathrm{pH}$ dependence than $\mathrm{Cd}$ [108]. Heavy metals become more soluble (leachable) under acidic conditions [109]. Hydrolysis of $\mathrm{Cu}$ at $\mathrm{pH}=6$ increases its retention in the soil, while $\mathrm{Cd}$ hydrolyzes up to $\mathrm{pH}=8$ [108]. At Locality III, a significant degree of binding was evident between $\mathrm{Pb}$ content and $\mathrm{pH}$ (spring and autumn) values, and between $\mathrm{Cd}$ content and $\mathrm{pH}$ (autumn) values. According to Kim et al. [110], the relative mobility of $\mathrm{Cd}$ in the soil solution is higher than $\mathrm{Pb}$. Li et al. [94] claim that higher concentrations of heavy metals have been observed at localities with higher $\mathrm{pH}$ values. According to Zhang et al. [111], low soil $\mathrm{pH}$ values are associated with some elements' intense leaching. The monitored soils' relatively high $\mathrm{pH}$ values could explain the weak correlation between $\mathrm{pH}$ and risk elements.

In our case, the correlation relationships were statistically significant between the contents of all heavy metals and the $\mathrm{pH}$ values, but the degree of their binding was different. It did not match the results obtained by Demková et al. [101] and Zhao et al. [105]. The results we researched correspond to the results obtained by Wang et al. [112]. Bołzan [108] states that metal cations' mobility increases with increasing soil $\mathrm{pH}$ values due to the formation of metal complexes with dissolved organic matter. Heavy metals tend to accumulate in soils with high $\mathrm{pH}$ values and organic substance content with a heavier structure [113]. One possible reason could be the low mobility of heavy metals in clay and alkaline soils [114].

By analyzing the total organic carbon content, we found that arable soils (Localities I-II) had a low TOC content in the monitored years. Similar values were measured as well by Šimanský et al. [115]. Each soil has its carbon capacity, and therefore, despite the addition of large amounts of carbon, the soil may not increase its carbon content proportionately [116]. An indispensable role of the ecosystem is the soil's organic carbon storage [117], depending on the balance of its inputs and outputs [118]. The post-harvest residues after combining harvesting into the soil were involved in the monitored localities, but the TOC contents were still low. These results do not fully correspond to the findings of Körschens et al. [119] and Cong et al. [117], stating that low organic carbon stocks are in soils that are not used for agricultural crop production (plant residues are not incorporated in soil). The decline in soil organic carbon reserves and possible loss in agricultural soils can also be affected by climate change and lower average annual temperatures [120-124]. Häring et al. [125] state that TOC stocks did not change depending on climatic, vegetation, and soil conditions. The authors Jiang et al. [126] indicate that soil factors and anthropogenic activities were directly influenced by soil's organic carbon content. However, long-term studies have shown that practices such as better fertilizer management, fertilization and composting, residue incorporation, crop rotation, green manure, reduced tillage, and modification of the irrigation method increase carbon formation and storage in the soil [127]. According to Lal et al. [128], these practices support sustainable agriculture and mitigate climate change.

At the monitored localities, we found that organic carbon content decreases depending on the depth in all soil units (Table 8). This matches the results obtained by Liu et al. [129] and Brady and Weil [130]. Studies that look at the impact of agrotechnical practices on TOC stocks primarily focus on the soil profile's surface layers [131]. According to Rumpel and Kögel-Knabner [132], the primary sources of organic matter in the subsoil are dissolved organic carbon, plant roots and root secretions, and particles' transport from the surface. By analyzing the results, we concluded that for the storage of organic carbon in surface and subsurface soil layers of the monitored localities, fertilization with NPK fertilizers had an effect. The results of further long-term experiments showed that with the application of inorganic fertilizers, the organic carbon content in the soil changed and either increased $[116,133]$ or remained at the same level, or only slightly increased over the years [127]. Only the average TOC content, calculated from measured TOC values at Locality III (Table 8) corresponded with the results of Zhang et al. [134]. It is known that 
maintaining organic carbon stocks in agricultural soils is essential to ensure food security. Under long-term constant management and environmental conditions, agricultural stocks of organic carbon are in a dynamic balance between $C$ inputs (crop residues, organic fertilizers, and decomposition of soil organic matter) [135].

In the final part, we analyzed the statistically significant difference of three monitored localities in the observed features: $\mathrm{pH}\left(\mathrm{H}_{2} \mathrm{O}\right), \mathrm{pH}(\mathrm{KCl})$, and TOC values in two seasons (spring and autumn, 2017-2019). The Kruskal-Wallis test confirmed that the observed values were statistically significantly different (Tables 10 and 11). The multiple comparison test confirmed that Locality III was statistically significantly different from Locality I in $\mathrm{pH}$ (active and exchange) values. The results correspond to the works of several other authors [136-139]. According to Balang [137], the exchange soil reaction expresses a more stable, long-term soil condition than the active soil reaction. Different soil units and the same land use had different soil $\mathrm{pH}$ values [138]. Most studies that monitor soil acidification during periods focus only on the topsoil, and attention is generally focused on the transition from neutral to acidic soil $\mathrm{pH}[136,139]$. There is no statistically significant difference in TOC content analyzed in soil samples. Soil organic carbon content can decrease soil acidification and affect soil $\mathrm{pH}$ values [140]. In the current pedogenesis stage, Slovak agricultural soils' carbon content is only satisfactory [141]. Changes in soil organic carbon levels in arable soil vary depending on the soil type [140].

By analyzing the content of heavy metals in plant parts (Table 13), we found that at Localities I-III, higher values of heavy metals were determined in the root system than in other new parts of the wheat. Bioavailable forms of $\mathrm{Zn}$ and $\mathrm{Cu}$ content in soil samples did not exceed the critical values. $\mathrm{Pb}$ content values exceeded the limit value for heavy metals concerning agricultural land and plant-critical values (Table 12). Xing et al. [142] state in their work that pollution of agricultural land often leads to increased concentrations of $\mathrm{Cd}$ and $\mathrm{Pb}$ in crops such as wheat. Rodriguez-Bocanegra et al. [11] found in their study that the analyzed soil had high contamination of $\mathrm{Cu}, \mathrm{Pb}$ and $\mathrm{Zn}$ content mainly in arable soil. Many of these heavy metals were bioavailable to plants, especially $\mathrm{Zn}$. Besides that, they confirmed that plants generally accumulate a higher content of heavy metals in the root system than in other new parts. The authors Kumpiene et al. [143] state that phosphorus application reduces bioavailable $\mathrm{Pb}$, thus reducing accumulation in plant shoots. This corresponds to the conclusions we reached in our research.

Cd occurred only in the root, in the above-ground parts in our analyzed parts of wheat, and $\mathrm{Cd}$ content was not found in the grain. We recorded lead in the root and the aboveground parts of wheat, but there was zero grain content. We conclude that the accumulation of $\mathrm{Cd}$ in plant, can be influenced by $\mathrm{pH}$ values, TOC values, plant nutrients, and the plant itself (species, variety, or cultivar). Gao et al. [144] reached similar conclusions. According to McLaughlin et al. [145], environmental factors may promote greater Cd uptake by increased flux to the root. The addition of $\mathrm{Ca}^{2+}$ ions through liming can lead to increased $\mathrm{Cd}$ solubility and availability to plants [146]. Plants grown on low $\mathrm{pH}$ soils, where Cd's solubility is highest, may pose a potentially high risk to consumers. Wheat grown on soils with low $\mathrm{Zn}$ and $\mathrm{P}$ bioavailability may have higher $\mathrm{Cd}$ concentrations in the grains [54]. The availability of macronutrients and micronutrients, such as $\mathrm{Zn}$, also affect $\mathrm{Cd}$ 's absorption in plants [147]. Cadmium slows down the root system's growth and causes chlorosis, even necrosis, with an overall decrease in biomass and yields [26]. We have reached similar results in our research as well. By analyzing the plants, we found that the accumulation of $\mathrm{Zn}$ content in crops depends primarily on Zn's soil availability. In our measurements, Zn content did not exceed the permitted limit value in any monitored localities. Studies by other researchers have shown that Zn's availability in the soil depends not only on the total $\mathrm{Zn}$ content of the soil but also on the influence of the physicochemical properties of the soil $[148,149]$. The low availability of $\mathrm{Zn}$ is often reported for wheat grains [70]. It is essential to improve $\mathrm{Zn}$ 's availability in crops through agricultural management practices such as zinc fertilizer application [150]. 
At Localities I-III, we also included in the calculation the results of analyses of whole plant parts (Table 13). According to the bioaccumulation coefficient values, potentially heavy metals, $\mathrm{Zn}$ and $\mathrm{Cu}$, in monitored localities can be classified into a class among the elements with an average intensity of accumulation. The calculated values of the bioaccumulation coefficient $\mathrm{Cd}$ for Locality I place it among the negligible accumulated metals. But for Locality II and Locality III these are intensively accumulated metals. The bioaccumulation coefficient values in all monitored localities classify $\mathrm{Pb}$ among the metals with average accumulation intensity. A similar conclusion was reached by Peijnenburg et al. [151]. Furthermore, according to Norouzi et al. [152] and Demková et al. [153], the concentrations of heavy metals in plants depend on the root uptake associated with the bioavailability of the elements in the soil or by dry and wet deposition on the external organs of plants. Heavy metals that bind to solid particles in the atmosphere can enter and contaminate the soil, given that the absorption of metal in higher plants occurs through the roots and leaves.

\section{Conclusions}

Our task is to avoid increasing concentrations of heavy metals in soil. Their accumulation affects the soil's ability to provide safe food, affects the quality and yields of cultivated crops, and impacts consumers' health. This is especially true for the contents of heavy metals with a high degree of biotoxicity.

Today, different procedures are used regarding sustainable agriculture; one possibility is the circular economy. The circular economy is focused on the (re)design of processes and products, aiming to minimize negative environmental impacts by reducing the use of non-renewable resources and improving waste management [154]. Agricultural production seeks to prevent soil degradation [155] and use amounts of fertilizer that do not change the soil's properties [135] while still increasing plant yields and productivity. This agricultural activity is a sustainable development component which affects food producers in difficult qualitative and quantitative conditions. Agricultural ecosystems are an important component in the production of food of plant and animal origin for humans. Heavy metal bioaccumulation in edible parts of plants seriously affects environmental components, the food chain, and the quality of people's lives, especially today, when the growing number of emerging diseases such as COVID-19 represents an increasing health risk.

The data obtained from the study on the content of heavy metals in soil and cereals grown in this soil should lead to appropriate measures related to food safety [156]. These are preventive measures to exclude heavy metals from the food chain. They may also include checking the bioavailability of the elements (e.g., by liming or using other methods to demobilize heavy metals), growing plants other than cereals on the affected land, and eventually remediation actions. The assessment results based on the soil samples from our study also highlight the need for spatially intensified and thematically broadened monitoring of soil resources in a monitored area. Heavy metals can be in agricultural soil from anthropogenic sources (transport and industrial) and dry and wet deposition. This also applies to the monitored sites; whose arable soils are in the vicinity of inhabited urban areas or near roads where the limits of $\mathrm{Cd}$ and $\mathrm{Pb}$ heavy metal content have been exceeded.

The main reasons for Cd's presence in the soil can be the use of large amounts of inorganic fertilizers, agrochemicals, and atmospheric deposits. Higher $\mathrm{Pb}$ contents may be mainly from anthropogenic sources (burning of fossil fuels and municipal sources), including transport and industrial resources. Exceeding the limits of heavy metals results in a threat to human health and direct negative economic impacts. To reduce heavy metals in the soil, stricter regulation of ash emissions during the coal combustion process could be introduced, especially in winter seasons, to mitigate the growing agricultural use of these heavy metals in arable soils. One effective solution to prevent and reduce soil contamination is for surface layers of soil to contain buffers, which would prevent pollutants from reaching deeper into the soil.

Regular monitoring and evaluation of the heavy metal content in soil units are of primary importance in this field. Current knowledge points to a comprehensive approach 
to tackling soil contamination and cultivated crops (plants) with heavy metals, which is necessary to maintain the soil's ecological function and ensure the health and food safety of cultivated cereals.

Author Contributions: Conceptualization: M.F.; L.P. and A.T.; methodology: M.F. and L.P.; validation: A.T.; formal analysis: A.T. and M.F.; data curation: A.T. and M.F.; writing-original draft preparation: M.F., L.P. and A.T.; writing—review and editing: M.F. All authors have read and agreed to the published version of the manuscript.

Funding: This research received no external funding.

Institutional Review Board Statement: Not applicable.

Informed Consent Statement: Not applicable.

Data Availability Statement: The data presented in this study is available upon request from the corresponding author.

Acknowledgments: This work has been supported by the Cultural and Educational Grant Agency (KEGA) of the Ministry of Education, Science, Research, and Sport of the Slovak Republic under the Grant No. 015UKF-4/2022, co-founded by the European Community under project No. 26220220180: Building Research Centre "AgroBioTech", and the Slovak Research and Development Agency under the contract No. APVV-14-0446.

Conflicts of Interest: The authors declare no conflict of interest.

\section{References}

1. Zhang, S.; Lin, H.; Deng, L.; Gong, G.; Jia, Y.; Xu, X.; Li, T.; Li, Y.; Chen, H. Cadmium tolerance and accumulation characteristics of Siegesbeckia orientalis L. Ecol. Eng. 2013, 51, 133-139. [CrossRef]

2. Steffan, J.J.; Brevik, E.C.; Burgess, L.C.; Cerdàcet, A. The effect of soil on human health: An overview. Eur. J. Soil Sci. 2018, 69, 159-171. [CrossRef]

3. Brevik, E.C. Soils and human health: An overview. In Soils and Human Health; Brevik, E.C., Burgess, L.C., Eds.; CRC Press: Boca Raton, FL, USA, 2013; pp. 29-56.

4. Von Lindern, I.; Spalinger, S.; Stifelman, M.L.; Stanek, L.W.; Bartrem, C. Estimating Children's Soil/Dust Ingestion Rates through Retrospective Analyses of Blood Lead Biomonitoring from the Bunker Hill Superfund Site in Idaho. Environ. Health Perspect. 2016, 124, 1462-1470. [CrossRef] [PubMed]

5. Xing, W.; Zhao, Q.; Scheckel, K.; Zheng, L.; Li, L. Inhalation bioaccessibility of $\mathrm{Cd}, \mathrm{Cu}, \mathrm{Pb}$ and $\mathrm{Zn}$ and speciation of $\mathrm{Pb}$ in particulate matter fractions from areas with different pollution characteristics in Henan Province, China. Ecotoxicol. Environ. Saf. 2019, 175, 192-200. [CrossRef]

6. Brevik, E.C.; Burgess, L.C. Soil: Influence on Human Health. In Encyclopedia of Environmental Management; Jorgensen, S.V., Ed.; CRC Press: Boca Raton, FL, USA, 2015; pp. 1-13.

7. Steinnes, E. Soils and human health. In Sustaining Soil Productivity in Response to Global Climate Change: Science, Policy, and Ethics; Sauer, T., Norman, J.M., Sivakumar, M.V.K., Eds.; John Wiley \& Sons. Inc.: Chichester, UK, 2011; pp. 79-86.

8. Green, H.; Broun, P.; Cakmak, I.; Condon, L.; Fedoroff, N.; Gonzalez-Valero, J.; Graham, I.; Lewis, J.; Moloney, M.; Oniang'O, R.K.; et al. Planting seeds for the future of food. J. Sci. Food Agric. 2016, 96, 1409-1414. [CrossRef] [PubMed]

9. Tóth, G.; Hermann, T.; Da Silva, M.; Montanarella, L. Heavy metals in agricultural soils of the European Union with implications for food safety. Environ. Int. 2016, 88, 299-309. [CrossRef]

10. Zeng, Y.; Lai, Z.; Yang, W.; Li, H. Distribution of heavy metals in surface sediments from the Pearl River outlets. South China: Five-year monitoring program. Fresen. Environ. Bull. 2018, 27, 574-583.

11. Rodríguez-Bocanegra, J.; Roca, N.; Febrero, A.; Bort, J. Assessment of heavy metal tolerance in two plant species growing in experimental disturbed polluted urban soil. J. Soil. Sediment. 2018, 18, 2305-2317. [CrossRef]

12. Zhang, X.; Yang, L.; Li, Y.; Li, H.; Wang, W.; Ye, B. Impacts of lead/zinc mining and smelting on the environment and human health in China. Environ. Monit. Assess. 2012, 184, 2261-2273. [CrossRef]

13. Pepper, I.L. The Soil Health-Human Health Nexus. Crit. Rev. Environ. Sci. Technol. 2013, 43, 2617-2652. [CrossRef]

14. Oliver, M.A.; Gregory, P.J. Soil, food security and human health: A review. Eur. J. Soil Sci. 2014, 66, 257-276. [CrossRef]

15. Pandey, S.; Parvez, S.; Sayeed, I.; Haque, R.; Bin-Hafeez, B.; Raisuddin, S. Biomarkers of oxidative stress: A comparative study of river Yamuna fish Wallago attu (Bl. \& Schn.). Sci. Total Environ. 2003, 309, 105-115. [CrossRef]

16. Li, Z.; Ma, Z.; van der Kuijp, T.J.; Yuan, Z.; Huang, L. A review of soil heavy metal pollution from mines in China: Pollution and health risk assessment. Sci. Total Environ. 2014, 468-469, 843-853. [CrossRef]

17. Satpathy, D.; Reddy, M.V.; Dhal, S.P. Risk Assessment of Heavy Metals Contamination in Paddy Soil, Plants, and Grains (Oryza sativa L.) at the East Coast of India. BioMed Res. Int. 2014, 2014, 1-11. [CrossRef] [PubMed] 
18. Hu, B.; Wang, J.; Jin, B.; Li, Y.; Shi, Z. Assessment of the potential health risks of heavy metals in soils in a coastal industrial region of the Yangtze River Delta. Environ. Sci. Pollut. Res. Int. 2017, 24, 19816-19826. [CrossRef] [PubMed]

19. Liu, Q.; Liu, J.; Wang, Q.; Wang, Y. Source identification and availability of heavy metals in peri-urban vegetable soils: A case study from China. Hum. Ecol. Risk Assess. Int. J. 2016, 22, 1-14.

20. Navarrete, I.A.; Gabiana, C.; Dumo, J.R.E.; Salmo Severino, S.G., III; Guzman, M.A.L.G.; Valera, N.S.; Espiritu, E.Q. Heavy metal concentrations in soils and vegetation in urban areas of Quezon City. Philippines. Environ. Monit. Assess. 2017, 189, 1-15. [CrossRef]

21. Stocking, M.A. Tropical Soils and Food Security: The Next 50 Years. Science 2003, 302, 1356-1359. [CrossRef]

22. Combs, G.F., Jr. Geological impacts on nutrition. In Essentials of Medical Geology; Selinus, O., Alloway, B., Centeno, J.A., Finkelman, R.B., Fuge, R., Lindh, U., Smedley, P., Eds.; Elsevier: Dordrecht, The Netherlands, 2005; pp. 161-177.

23. Henry, J.M.; Cring, F.D. Geophagy: An anthropological perspective. In Soils and Human Health; Brevik, E.C., Burgess, L.C., Eds.; CRC Press: Boca Raton, FL, USA, 2013; pp. 179-198.

24. Nagajyoti, P.C.; Lee, K.D.; Sreekanth, T.V.M.; Nagajyoti, P.C.; Lee, K.D.; Sreekanth, T.V.M. Heavy metals, occurrence and toxicity for plants: A review. Environ. Chem. Lett. 2010, 8, 199-216. [CrossRef]

25. Rattan, R.; Datta, S.; Chhonkar, P.; Suribabu, K.; Singh, A. Long-term impact of irrigation with sewage effluents on heavy metal content in soils, crops and groundwater-A case study. Agric. Ecosyst. Environ. 2005, 109, 310-322. [CrossRef]

26. Urminská, J.; Tóth, T.; Prokeinová, R.B.; Ondrišík, P. The effect of the selected remediation medium on the cadmium bioavailability in the selected ecosystem in the Southwestern locality of Slovakia. Ekológia 2019, 38, 214-224. [CrossRef]

27. Wu, L.; Pan, X.; Chen, L.; Huang, Y.; Teng, Y.; Luo, Y.; Christie, P. Occurrence and distribution of heavy metals and tetracyclines in agricultural soils after typical land use change in east China. Environ. Sci. Pollut. Res. Int. 2013, 20, 8342-8354. [CrossRef] [PubMed]

28. Ding, Q.; Cheng, G.; Wang, Y.; Zhuang, D. Effects of natural factors on the spatial distribution of heavy metals in soils surrounding mining regions. Sci. Total Environ. 2017, 578, 577-585. [CrossRef] [PubMed]

29. Shen, F.; Liao, R.; Ali, A.; Mahar, A.; Guo, D.; Li, R.; Xining, S.; Awasthi, M.K.; Wang, Q.; Zhang, Z. Spatial distribution and risk assessment of heavy metals in soil near a $\mathrm{Pb} / \mathrm{Zn}$ smelter in Feng County, China. Ecotoxico. Environ. Saf. 2017, 139, 254-262. [CrossRef]

30. Lin, Y.-P.; Teng, T.-P.; Chang, T.-K. Multivariate analysis of soil heavy metal pollution and landscape pattern in Changhua county in Taiwan. Landsc. Urban Plan. 2002, 62, 19-35. [CrossRef]

31. Shi, T.; Ma, J.; Wu, X.; Ju, T.; Lin, X.; Zhang, Y.; Li, X.; Gong, Y.; Hou, H.; Zhao, L.; et al. Inventories of heavy metal inputs and outputs to and from agricultural soils: A review. Ecotoxicol. Environ. Saf. 2018, 164, 118-124. [CrossRef]

32. Hauptvogl, M.; Kotrla, M.; Prčík, M.; Pauková, Ž.; Kováčik, M.; Lošák, T. Phytoremediation Potential of Fast-Growing Energy Plants: Challenges and Perspectives-A Review. Pol. J. Environ. Stud. 2019, 29, 505-516. [CrossRef]

33. Schwarz, K.; Pickett, S.T.A.; Lathrop, R.G.; Weathers, K.C.; Pouyat, R.V.; Cadenasso, M.L. The effects of the urban built environment on the spatial distribution of lead in residential soils. Environ. Pollut. 2012, 163, 32-39. [CrossRef]

34. Djingova, R.; Kuleff, I. Instrumental Techniques for Trace Analysis. In Trace Elements-Their Distribution and Effects in the Environment; Vernet, J.P., Ed.; Elsevier: London, UK, 2000; pp. 137-185.

35. Hu, W.; Huang, B.; Tian, K.; Holm, P.E.; Zhang, Y. Heavy metals in intensive greenhouse vegetable production systems along Yellow Sea of China: Levels, transfer and health risk. Chemosphere 2017, 167, 82-90. [CrossRef] [PubMed]

36. Viventsova, E.; Kumpiene, J.; Gunneriusson, L.; Holmgren, A. Changes in soil organic matter composition and quantity with distance to a nickel smelter-a case study on the Kola Peninsula, NW Russia. Geoderma 2005, 127, 216-226. [CrossRef]

37. Park, J.H.; Lamb, D.; Paneerselvam, P.; Choppala, G.; Bolan, N.; Chung, J.-W. Role of organic amendments on enhanced bioremediation of heavy metal(loid) contaminated soils. J. Hazard. Mater. 2011, 185, 549-574. [CrossRef]

38. Mahar, A.; Wang, P.; Li, R.; Zhang, Z. Immobilization of Lead and Cadmium in Contaminated Soil Using Amendments: A Review. Pedosphere 2015, 25, 555-568. [CrossRef]

39. Wiszniewska, A.; Hanus-Fajerska, E.; Muszyńska, E.; Ciarkowska, K. Natural Organic Amendments for Improved Phytoremediation of Polluted Soils: A Review of Recent Progress. Pedosphere 2016, 26, 1-12. [CrossRef]

40. Beesley, L.; Moreno-Jiménez, E.; Gomez-Eyles, J.L.; Harris, E.; Robinson, B.; Sizmur, T. A review of biochars' potential role in the remediation. revegetation and restoration of contaminated soils. Environ. Pollut. 2011, 159, 3269-3282. [CrossRef] [PubMed]

41. Komárek, M.; Vanek, A.; Ettler, V. Chemical stabilization of metals and arsenic in contaminated soils using oxides-A review. Environ. Pollut. 2013, 172, 9-22. [CrossRef]

42. Bolan, N.; Kunhikrishnan, A.; Thangarajan, R.; Kumpiene, J.; Park, J.; Makino, T.; Kirkham, M.B.; Scheckel, K. Remediation of heavy metal(loid)s contaminated soils-To mobilize or to immobilize? J. Hazard. Mater. 2014, 266, 141-166. [CrossRef]

43. Hernandez-Soriano, M.C.; Jimenez-Lopez, J.C. Effects of soil water content and organic matter addition on the speciation and bioavailability of heavy metals. Sci. Total Environ. 2012, 423, 55-61. [CrossRef]

44. Jing, F.; Chen, C.; Chen, X.; Liu, W.; Wen, X.; Hu, S.; Yang, Z.; Guo, B.; Xu, Y.; Yu, Q. Effects of wheat straw derived biochar on cadmium availability in a paddy soil and its accumulation in rice. Environ. Pollut. 2020, 257, 113592. [CrossRef]

45. Nordberg, G.F.; Fowler, B.; Nordberg, M. Cadmium. In Handbook on the Toxicology of Metals, 4th ed.; Nordberg, G.F., Fowler, B.A., Nordberg, M., Eds.; Elsevier: Amsterdam, The Netherlands, 2015; Volume 2, pp. 667-716. 
46. Makovníková, J.; Barančíková, G.; Dlapa, P.; Dercová, K. Anorganické kontaminanty v pôdnom ekosystéme. Chem. Listy 2006, $100,424-432$.

47. Halušková, L.; Valentovičová, K.; Huttová, J.; Mistrík, I.; Tamás, L. Effect of heavy metals on root growth and peroxidase activity in barley root tip. Acta Physiol. Plant. 2010, 32, 59-65. [CrossRef]

48. Cobbett, C.; Goldsbrough, P. Phytochelatins and Metallothioneins: Roles in Heavy Metal Detoxification and Homeostasis. Annu. Rev. Plant Biol. 2002, 53, 159-182. [CrossRef] [PubMed]

49. Chandrasekaran, A.; Ravisankar, R.; Harikrishnan, N.; Satapathy, K.; Prasad, M.; Kanagasabapathy, K. Multivariate statistical analysis of heavy metal concentration in soils of Yelagiri Hills, Tamilnadu, India-Spectroscopical approach. Spectrochim. Acta Part A Mol. Biomol. Spectrosc. 2015, 137, 589-600. [CrossRef]

50. Yang, Y.; Chen, W.; Wang, M.; Peng, C. Regional accumulation characteristics of cadmium in vegetables: Influencing factors, transfer model and indication of soil threshold content. Environ. Pollut. 2016, 219, 1036-1043. [CrossRef]

51. Hunter, P. A toxic brew we cannot live without-Micronutrients give insights into the interplay between geochemistry and evolutionary biology. EMBO Rep. 2008, 9, 15-18. [CrossRef]

52. Engström, A.; Michaëlsson, K.; Vahter, M.; Julin, B.; Wolk, A.; Åkesson, A. Associations between dietary cadmium exposure and bone mineral density and risk of osteoporosis and fractures among women. Bone 2012, 50, 1372-1378. [CrossRef]

53. Ju, Y.-R.; Chen, W.-Y.; Liao, C.-M. Assessing human exposure risk to cadmium through inhalation and seafood consumption. J. Hazard. Mater. 2012, 227-228, 353-361. [CrossRef]

54. Yi, Z.; Lehto, N.J.; Robinson, B.H.; Cavanagh, J.-A.E. Environmental and edaphic factors affecting soil cadmium uptake by spinach, potatoes, onion and wheat. Sci. Total Environ. 2020, 713, 136694. [CrossRef]

55. Braungardt, C.B.; Achterberg, E.P.; Axelsson, B.; Buffle, J.; Graziottin, F.; Howell, K.A.; Illuminati, S.; Scarponi, G.; Tappin, A.D.; Tercier-Waeber, M.-L.; et al. Analysis of dissolved metal fractions in coastal waters: An inter-comparison of five voltammetric in situ profiling (VIP) systems. Mar. Chem. 2009, 114, 47-55. [CrossRef]

56. Vamerali, T.; Bandiera, M.; Mosca, G. Field crops for phytoremediation of metal-contaminated land. A review. Environ. Chem. Lett. 2009, 8, 1-17. [CrossRef]

57. Yruela, I. Copper in plants: Acquisition, transport and interactions. Funct. Plant Biol. 2009, 36, 409-430. [CrossRef] [PubMed]

58. Bhattacharya, P.T.; Misra, S.R.; Hussain, M. Nutrition Aspects of Essential Trace Elements in Oral Health and Disease: An Extensive Rewiew. Scientifica 2016, 2016, 5464373. [CrossRef]

59. Balabanova, B.; Stafilov, T.; Šajn, R.; Andonovska, K.B. Quantitative assessment of metal elements using moss species as biomonitors in downwind area of lead-zinc mine. J. Environ. Sci. Health Part A 2016, 52, 290-301. [CrossRef]

60. Nabulo, G.; Oryem-Origa, H.; Diamond, M. Assessment of lead, cadmium, and zinc contamination of roadside soils, surface films, and vegetables in Kampala City, Uganda. Environ. Res. 2006, 101, 42-52. [CrossRef] [PubMed]

61. Beneš, S. Obsahy a Bilance Prokư ve Sférach Životního Prostředí, II. část; Ministerstvo Zemědelství ČR: Praha, Czech Republic, 1994; $184 \mathrm{p}$.

62. Matovic, V.; Buha, A.; Đukić-Ćosić, D.; Bulat, Z. Insight into the oxidative stress induced by lead and/or cadmium in blood, liver and kidneys. Food Chem. Toxicol. 2015, 78, 130-140. [CrossRef] [PubMed]

63. Hronec, O.; Tóth, J.; Tomáš, J. Cudzorodé Látky a Ich Riziká; Harlequin Quality Ltd.: Košice, Slovakia, 2002; 200p.

64. Vallascas, E.; De Micco, A.; Deiana, F.; Banni, S.; Sanna, E. Adipose tissue: Another target organ for lead accumulation? A study on sardinian children (Italy). Am. J. Hum. Biol. 2013, 25, 789-794. [CrossRef] [PubMed]

65. Li, Y.; Wu, S.; Xiang, Y.; Liang, X. An investigation of outpatient children's blood lead level in Wuhan China. PLoS ONE 2014, 9, e95284. [CrossRef]

66. Morgan, R. Soil. heavy metals, and human health. In Soils and Human Health; Brevik, E.C., Burgess, L.C., Eds.; CRC Press: Boca Raton, FL, USA, 2013; pp. 59-82.

67. Sharma, V.K.; McDonald, T.J.; Sohn, M.; Anquandah, G.A.K.; Pettine, M.; Zboril, R. Biogeochemistry of selenium. A review. Environ. Chem. Lett. 2015, 13, 49-58. [CrossRef]

68. Alloway, B.J. Zinc in Soil and Crop Nutrition, 2nd ed.; IZA and IFA: Brussels, Belgium; Paris, France, 2008; 135p.

69. Baize, D.; Sterckeman, T. Of the necessity of knowledge of the natural pedo-geochemical background content in the evaluation of the contamination of soils by trace elements. Sci. Total Environ. 2001, 264, 127-139. [CrossRef]

70. Liu, Y.-M.; Liu, D.-Y.; Zhao, Q.-Y.; Zhang, W.; Chen, X.-X.; Xu, S.-J.; Zou, C.-Q. Zinc fractions in soils and uptake in winter wheat as affected by repeated applications of zinc fertilizer. Soil Tillage Res. 2020, 200, 104612. [CrossRef]

71. Linkeš, V.; Pestún, V.; Džatko, M. Príručka Pre Používanie Máp Bonitovaných Pôdno_Ekologických Jednotiek. Príručka Pre Bonitáciu Pol'nohospodárskych Pôd, 3rd ed.; VÚPÚ: Bratislava, Slovakia, 1996; 104p.

72. Bátora, M.; Zat'ko, M. Zlaté Moravce, 1st ed.; Mestský úrad: Zlaté Moravce, Slovakia, 1998; 373p.

73. Süle, P.; Šüle, P.M.L.; Adamová, M. Encyklopédia Miest a obcí Slovenska; PS-LINE. spol. s r. o.: Lučenec, Slovakia, 2005; 960p.

74. Balkovič, J.; Bedrna, Z.; Bublinec, E.; Čurlík, J.; Dlapa, P.; Fulajtár, E.; Gömöryová, E.; Gregor, J.; Hanes, J.; Houšková, B.; et al. Morfogenetický Klasifikačný Systém Pôd Slovenska. In Bazálna Referenčná Taxonómia, 2nd ed.; SPS. NPPC VÚPOP: Bratislava, Slovakia, 2014; 96p.

75. Decree of the National Council of the Slovak Republic No. 59/2013 Coll. Ministry of Agriculture and Rural Development of the Slovak Republic, which amends Decree of the Ministry of Agriculture of the Slovak Republic No. 508/2004 Coll., Which Implements $\S 27$ of Act No. 220/2004 Coll. on the Protection and Use of Agricultural Land and Amending Act No. 245/2003 
Coll. on Integrated Prevention and Control of Environmental Pollution and Amendments to Certain Acts. Available online: https: / / www.slov-lex.sk/vyhladavanie-pravnych-predpisov?text=59\%2F2013\%20 (accessed on 2 February 2021).

76. Decree of the Ministry of Agriculture of the Slovak Republic No. 508/2004 Coll., Which Implements § 27 of Act No. $220 / 2004$ Coll. on the Protection and Use of Agricultural Land and Amending Act No. 245/2003 Coll. on Integrated Prevention and Control of Environmental Pollution and Amendments to Certain Acts. Available online: https://www.slov-lex.sk/pravnepredpisy/SK/ZZ/2004/508/20130401 (accessed on 5 February 2021).

77. Van Reeuwijk, L.P. Producer for Soil Analysis; International Soil reference and Information Centre: Wageningen, The Netherlands, 2002; 120p.

78. Orlov, D.S.; Grišina, L.A. Praktikum po Chimiji Gumusa; Izdatel'stvo Moskovskovo Uniresiteta: Moscow, Russia, 1981; 124p.

79. Grišina, L.A. Gumusoobrazovanije i Gumusnoe Sostojanije Počv; Izd. MU: Moskva, Russia, 1986; 242p.

80. Liu, W.-X.; Shen, L.-F.; Liu, J.-W.; Wang, Y.-W.; Li, S.-R. Uptake of Toxic Heavy Metals by Rice (Oryza sativa L.) Cultivated in the Agricultural Soil near Zhengzhou City, People's Republic of China. Bull. Environ. Contam. Toxicol. 2007, 79, 209-213. [CrossRef]

81. Markechová, D.; Stehlíková, B.; Tirpáková, A. Štatistické Metódy a ich Aplikácie; UKF: Nitra, Slovakia, 2011; 534p.

82. Decree of the Ministry of Agriculture of the Slovak Republic and the Ministry of Health of the Slovak Republic of 29 October 2007 no. 14300/2007-OL. amending the Decree of the Ministry of Agriculture of the Slovak Republic and the Ministry of Health of the Slovak Republic of 11 September 2006 no. 18558/2006-SL. Issuing the Title of the Food Code of the Slovak Republic regulating Contaminants in Foodstuffs. Available online: https: / www.mpsr.sk/index.php?navID=126\&year=2007\&ofs1=4 (accessed on 15 March 2021).

83. State Veterinary and Food Administration of the Slovak Republic. Food Code of the Slovak Republic. Available online: https:/ / www.svps.sk/legislativa/legislativa_kodex.asp (accessed on 15 February 2021).

84. Rapant, S.; Cvečková, V.; Jurkovič, L'.; Macek, J. Aplikovaná Medicínska Geochémia; Univerzita Komenského v Bratislave: Bratislava, Slovakia, 2019; 163p.

85. Essentials of Medical Geology: Impacts of the Natural Environment on Public Health; Selinus, O.; Alloway, B.J.; Centeno, J.A.; Finkelman, R.B.; Fuge, R.; Lindh, U.; Smedley, P. (Eds.) Elsevier Acadamic Press: Burlington, MA, USA, 2005; 793p.

86. Wang, Z.; Xiao, J.; Wang, L.; Liang, T.; Guo, Q.; Guan, Y.; Rinklebe, J. Elucidating the differentiation of soil heavy metals under different land uses with geographically weighted regression and self-organizing map. Environ. Pollut. 2020, $260,114065$. [CrossRef]

87. Yuanan, H.; He, K.; Sun, Z.; Chen, G.; Cheng, H. Quantitative source apportionment of heavy metal(loid)s in the agricultural soils of an industrializing region and associated model uncertainty. J. Hazard. Mater. 2020, 391, 122244. [CrossRef]

88. Chen, T.; Wong, J.; Zhou, H.; Wong, M. Assessment of trace metal distribution and contamination in surface soils of Hong Kong. Environ. Pollut. 1997, 96, 61-68. [CrossRef]

89. Huang, B.; Shi, X.; Yu, D.; Öborn, I.; Blombäck, K.; Pagella, T.; Wang, H.; Sun, W.; Sinclair, F.L. Environmental assessment of small-scale vegetable farming systems in peri-urban areas of the Yangtze River Delta Region, China. Agric. Ecosyst. Environ. 2006, 112, 391-402. [CrossRef]

90. Duan, Q.; Lee, J.; Liu, Y.; Chen, H.; Hu, H. Distribution of Heavy Metal Pollution in Surface Soil Samples in China: A Graphical Review. Bull. Environ. Contam. Toxicol. 2016, 97, 303-309. [CrossRef] [PubMed]

91. Khan, M.A.; Khan, S.; Khan, A.; Alam, M. Soil contamination with cadmium, consequences and remediation using organic amendments. Sci. Total Environ. 2017, 601-602, 1591-1605. [CrossRef] [PubMed]

92. Feng, W.; Guo, Z.; Peng, C.; Xiao, X.; Shi, L.; Zeng, P.; Ran, H.; Xue, Q. Atmospheric bulk deposition of heavy metal(loid)s in central south China: Fluxes, influencing factors and implication for paddy soils. J. Hazard. Mater. 2019, 371, 634-642. [CrossRef] [PubMed]

93. Roca, N.; Pazos, M.S.; Bech, J. Background levels of potentially toxic elements in soils: A case study in Catamarca (a semiarid region in Argentina). Catena 2012, 92, 55-66. [CrossRef]

94. Li, C.; Sun, G.; Wu, Z.; Zhong, H.; Wang, R.; Liu, X.; Guo, Z.; Cheng, J. Soil physiochemical properties and landscape patterns control trace metal contamination at the urban-rural interface in southern China. Environ. Pollut. 2019, 250, 537-545. [CrossRef]

95. Ye, C.; Butler, O.M.; Du, M.; Liu, W.; Zhang, Q. Spatio-temporal dynamics, drivers and potential sources of heavy metal pollution in riparian soils along a 600 kilometre stream gradient in Central China. Sci. Total Environ. 2019, 651, 1935-1945. [CrossRef]

96. Belon, E.; Boisson, M.; Deportes, I.; Eglin, T.; Feix, I.; Bispo, A.; Galsomies, L.; Leblond, S.; Guellier, C. An inventory of trace elements inputs to French agricultural soils. Sci. Total Environ. 2012, 439, 87-95. [CrossRef] [PubMed]

97. Hu, W.; Wang, H.; Dong, L.; Huang, B.; Borggaard, O.K.; Hansen, H.C.B.; He, Y.; Holm, P.E. Source identification of heavy metals in peri-urban agricultural soils of southeast China: An integrated approach. Environ. Pollut. 2018, 237, 650-661. [CrossRef] [PubMed]

98. Zhao, S.; Qiu, S.; He, P. Changes of heavy metals in soil and wheat grain under long-term environmental impact and fertilization practices in North China. J. Plant Nutr. 2018, 41, 1970-1979. [CrossRef]

99. Shao, D.; Zhan, Y.; Zhou, W.; Zhu, L. Current status and temporal trend of heavy metals in farmland soil of the Yangtze River Delta Region: Field survey and meta-analysis. Environ. Pollut. 2016, 219, 329-336. [CrossRef] [PubMed]

100. Huang, J.; Guo, S.; Zeng, G.-M.; Li, F.; Gu, Y.; Shi, Y.; Shi, L.; Liu, W.; Peng, S. A new exploration of health risk assessment quantification from sources of soil heavy metals under different land use. Environ. Pollut. 2018, 243, 49-58. [CrossRef] [PubMed] 
101. Demková, L.; Bobulská, L.; Fazekášová, D. Toxicity of heavy metals to soil biological and chemical properties in conditions of environmentally polluted area middle Spiš (Slovakia). Carpath. J. Earth Env. 2015, 10, 193-201.

102. Chai, Y.; Guo, J.; Chai, S.; Cai, J.; Xue, L.; Zhang, Q. Source identification of eight heavy metals in grassland soils by multivariate analysis from the Baicheng-Songyuan area, Jilin Province, Northeast China. Chemosphere 2015, 134, 67-75. [CrossRef]

103. Lv, J.; Wang, J. Multi-scale analysis of heavy metals sources in soils of Jiangsu Coast. Eastern China. Chemosphere 2018, 212, 964-973. [CrossRef] [PubMed]

104. Zupančič, N. Influence of climate factors on soil heavy metal content in Slovenia. J. Soils Sediments 2017, 17, 1073-1083. [CrossRef]

105. Zhao, K.; Zhang, L.; Dong, J.; Wu, J.; Ye, Z.; Zhao, W.; Ding, L.; Fu, W. Risk assessment, spatial patterns and source apportionment of soil heavy metals in a typical Chinese hickory plantation region of southeastern China. Geoderma 2020, 360, 1-11. [CrossRef]

106. Laurent, C.; Bravin, M.N.; Crouzet, O.; Pelosi, C.; Tillard, E.; Lecomte, P.; Lamy, I. Increased soil pH and dissolved organic matter after a decade of organic fertilizer application mitigates copper and zinc availability despite contamination. Sci. Total Environ. 2020, 709, 135927. [CrossRef]

107. Jones, J.B. Soil pH. Liming, and liming materials. In Agronomic Handbook Management of Crops, Soils and Their Fertility; CRC Press: Washington, DC, USA, 2002; pp. 237-251.

108. Bołzan, B.D. Effect of pH and soil environment. World News Nat. Sci. 2017, 8, 50-60.

109. Wilson, M.; Bell, N. Acid deposition and heavy metal mobilization. Appl. Geochem. 1996, 11, 133-137. [CrossRef]

110. Kim, R.-Y.; Yoon, J.-K.; Kim, T.-S.; Yang, J.E.; Owens, G.; Kim, K.-R. Bioavailability of heavy metals in soils: Definitions and practical implementation-A critical review. Environ. Geochem. Health 2015, 37, 1041-1061. [CrossRef] [PubMed]

111. Zhang, X.P.; Deng, W.; Yang, X.M. The background concentrations of 13 soil trace elements and their relationships to parent materials and vegetation in Xizang (Tibet), China. J. Asian Earth Sci. 2002, 21, 167-174. [CrossRef]

112. Wang, Z.; Hong, C.; Xing, Y.; Wang, K.; Li, Y.; Feng, L.; Ma, S. Spatial distribution and sources of heavy metals in natural pasture soil around copper-molybdenum mine in Northeast China. Ecotoxicol. Environ. Saf. 2018, 154, 329-336. [CrossRef]

113. Kosheleva, N.E.; Kasimov, N.S.; Vlasov, D.V. Factors of the accumulation of heavy metals and metalloids at geochemical barriers in urban soils. Eurasian Soil Sci. 2015, 48, 476-492. [CrossRef]

114. Khorshid, M.S.H.; Thiele-Bruhn, S. Contamination status and assessment of urban and non-urban soils in the region of Sulaimani City, Kurdistan, Iraq. Environ. Earth Sci. 2016, 75, 1171. [CrossRef]

115. Šimanský, V.; Bajčan, D.; Ducsay, L. The effect of organic matter on aggregation under different soil management practices in a vineyard in an extremely humid year. Catena 2013, 101, 108-113. [CrossRef]

116. Purakayastha, T.; Rudrappa, L.; Singh, D.; Swarup, A.; Bhadraray, S. Long-term impact of fertilizers on soil organic carbon pools and sequestration rates in maize-wheat-cowpea cropping system. Geoderma 2008, 144, 370-378. [CrossRef]

117. Cong, W.-F.; van Ruijven, J.; Mommer, L.; De Deyn, G.B.; Berendse, F.; Hoffland, E. Plant species richness promotes soil carbon and nitrogen stocks in grasslands without legumes. J. Ecol. 2014, 102, 1163-1170. [CrossRef]

118. Sistla, S.A.; Moore, J.C.; Simpson, R.T.; Gough, L.; Shaver, G.R.; Schimel, J.P. Long-term warming restructures Arctic tundra without changing net soil carbon storage. Nature 2013, 497, 615-618. [CrossRef]

119. Körschens, M.; Albert, E.; Armbruster, M.; Barkusky, D.; Baumecker, M.; Behle-Schalk, L.; Bischoff, R.; Čergan, Z.; Ellmer, F.; Herbst, F.; et al. Effect of mineral and organic fertilization on crop yield, nitrogen uptake, carbon and nitrogen balances, as well as soil organic carbon content and dynamics: Results from 20 European long-term field experiments of the twenty-first century. Arch. Agron. Soil Sci. 2013, 59, 1017-1040. [CrossRef]

120. Von Lützow, M.; Kögel-Knaber, I. Temperature sensitivity of soil organic matter decomposition-What do we know? Biol. Fert. Soils 2009, 46, 1-15. [CrossRef]

121. Tarnocai, C.; Canadell, J.; Schuur, E.A.G.; Kuhry, P.; Mazhitova, G.; Zimov, S. Soil organic carbon pools in the northern circumpolar permafrost region. Glob. Biogeochem. Cycles 2009, 23, 1-11. [CrossRef]

122. Conant, R.T.; Ryan, M.G.; Agren, G.I.; Birge, H.E.; Davidson, E.A.; Eliasson, P.E.; Evans, S.E.; Frey, S.D.; Giardina, C.H.P.; Hopkins, F.M.; et al. Temperature and soil organic matter decomposition rates-synthesis of current knowledge and a way forward. Glob. Chang. Biol. 2011, 17, 3392-3404. [CrossRef]

123. Scharlemann, J.; Tanner, E.V.; Hiederer, R.; Kapos, V. Global soil carbon: Understanding and managing the largest terrestrial carbon pool. Carbon Manag. 2014, 5, 81-91. [CrossRef]

124. Wiesmeier, M.; Poeplau, C.; Sierra, C.; Maier, H.; Frühauf, C.; Hübner, R.; Kühnel, A.; Spoerlein, P.; Geuß, U.; Hangen, E.; et al. Projected loss of soil organic carbon in temperate agricultural soils in the 21st century: Effects of climate change and carbon input trends. Sci. Rep. 2016, 6, 1-17. [CrossRef] [PubMed]

125. Haring, V.; Fischer, H.; Cadisch, G.; Stahr, K. Implication of erosion on the assessment of decomposition and humification of soil organic carbon after land use change in tropical agricultural systems. Soil Biol. Biochem. 2013, 65, 158-167. [CrossRef]

126. Jiang, G.; Xu, M.; He, X.; Zhang, W.; Huang, S.; Yang, X.; Liu, H.; Peng, C.; Shirato, Y.; Iizumi, T.; et al. Soil organic carbon sequestration in upland soils of northern China under variable fertilizer management and climate change scenarios. Glob. Biogeochem. Cycles 2014, 28, 319-333. [CrossRef]

127. Nayak, A.; Gangwar, B.; Shukla, A.K.; Mazumdar, S.P.; Kumar, A.; Raja, R.; Kumar, A.; Kumar, V.; Rai, P.; Mohan, U. Long-term effect of different integrated nutrient management on soil organic carbon and its fractions and sustainability of rice-wheat system in Indo Gangetic Plains of India. Field Crops Res. 2012, 127, 129-139. [CrossRef] 
128. Lal, R.; Kimble, J.M.; Follett, R.F.; Cole, C.V. The Potential of U.S. Cropland to Sequester Carbon and Mitigate the Greenhouse Effect; Sleeping Bear Press: Chelsea, MI, USA, 1998; 128p.

129. Liu, X.; Han, X.; Song, C.; Herbert, S.J.; Xing, B. Soil Organic Carbon Dynamics in Black Soils of China Under Different Agricultural Management Systems. Commun. Soil Sci. Plant Anal. 2003, 34, 973-984. [CrossRef]

130. Brady, N.C.; Weil, R.R. The Nature and Properties of Soils, 14th ed.; Pearson Education Inc.: Upper Saddle River, NJ, USA, 2008; 965p.

131. Syswerda, S.; Corbin, A.; Mokma, D.; Kravchenko, A.; Robertson, G. Agricultural Management and Soil Carbon Storage in Surface vs. Deep Layers. Soil Sci. Soc. Am. J. 2011, 75, 92-101. [CrossRef]

132. Rumpel, C.; Kögel-Knabner, I. Deep soil organic matter-a key but poorly understood component of terrestrial C cycle. Plant Soil 2011, 338, 143-158. [CrossRef]

133. Zhang, W.; Xu, M.; Wang, B.; Wang, X. Soil organic carbon, total nitrogen and grain yields under long-term fertilizations in the upland red soil of southern China. Nutr. Cycl. Agroecosystems 2008, 84, 59-69. [CrossRef]

134. Zhang, J.; Balkovič, J.; Azevedo, L.B.; Skalský, R.; Bouwman, A.F.; Xu, G.; Wang, J.; Xu, M.; Yu, C. Analyzing and modelling the effect of long-term fertilizer management on crop yield and soil organic carbon in China. Sci. Total Environ. 2018, 627, 361-372. [CrossRef]

135. Galati, A.; Crescimanno, M.; Gristina, L.; Keesstra, S.; Novara, A. Actual provision as an alternative criterion to improve the efficiency of payments for ecosystem services for C sequestration in semiarid vineyards. Agric. Syst. 2016, 144, 58-64. [CrossRef]

136. Guo, J.H.; Liu, X.J.; Zhang, Y.; Shen, J.L.; Han, W.X.; Zhang, W.F.; Christie, P.; Goulding, K.; Vitousek, P.M.; Zhang, F.; et al. Significant Acidification in Major Chinese Croplands. Science 2010, 327, 1008-1010. [CrossRef] [PubMed]

137. Pal'ove-Balang, P. Prijem a Transport Minerálnych Látok v Rastlinách; Univerzita Pavla Jozefa Šafárika: Košice, Slovakia, 2012; pp. 11-12.

138. Filippi, P.; Cattle, S.R.; Bishop, T.; Odeh, I.O.; Pringle, M.J. Digital soil monitoring of top- and sub-soil pH with bivariate linear mixed models. Geoderma 2018, 322, 149-162. [CrossRef]

139. Marchant, B.P.; Crawford, D.M.; Robinson, N.J. What can legacy datasets tell us about soil quality trends? Soil acidity in Victoria. In Proceeding of the IOP Conference Series: Earth and Environmental Science, Bendigo, Australia, $24-27$ March 2014.

140. Bowman, W.D.; Cleveland, C.C.; Halada, L.; Hreško, J.; Baron, J.S. Negative impact of nitrogen deposition on soil buffering capacity. Nat. Geosci. 2008, 1,767-770. [CrossRef]

141. Bielek, P. Kompendium Praktického Pôdoznalectva, 1st ed.; Slovenská pol'nohospodárska Univerzita: Nitra, Slovakia, 2014; 244p.

142. Xing, W.; Zhang, H.; Scheckel, K.G.; Li, L. Heavy metal and metalloid concentrations in components of 25 wheat (Triticum aestivum) varieties in the vicinity of lead smelters in Henan province, China. Environ. Monit. Assess. 2016, 188, 1-10. [CrossRef]

143. Kumpiene, J.; Antelo, J.; Brännvall, E.; Carabante, I.; Ek, K.; Komárek, M.; Söderberg, C.; Wårell, L. In situ chemical stabilization of trace element-contaminated soil-Field demonstrations and barriers to transition from laboratory to the field-A review. Appl. Geochem. 2019, 100, 335-351. [CrossRef]

144. Gao, X.; Brown, K.R.; Racz, G.J.; Grant, C.A. Concentration of cadmium in durum wheat as affected by time, source and placement of nitrogen fertilization under reduced and conventional-tillage management. Plant Soil 2010, 337, 341-354. [CrossRef]

145. McLaughlin, M.J.; Smolders, E.; Degryse, F.; Rietra, R. Uptake of Metals from Soil into Vegetables. In Dealing with Contaminated Sites; Swartjes, F., Ed.; Springer: Dordrecht, The Netherland, 2011; pp. 325-367.

146. Shaheen, S.; Rinklebe, J. Impact of emerging and low cost alternative amendments on the (im)mobilization and phytoavailability of $\mathrm{Cd}$ and $\mathrm{Pb}$ in a contaminated floodplain soil. Ecol. Eng. 2015, 74, 319-326. [CrossRef]

147. Chaney, R.L. Food Safety Issues for Mineral and Organic Fertilizers. Adv. Agron. 2012, 117, 51-116. [CrossRef]

148. Soltani, S.M.; Hanafi, M.M.; Wahid, S.A.; Kharidah, S.M.S. Zinc fractionation of tropical paddy soils and their relationships with selected soil properties. Chem. Speciat. Bioavailab. 2015, 27, 53-61. [CrossRef]

149. Antoniadis, V.; Shaheen, S.; Tsadilas, C.; Selim, M.H.; Rinklebe, J. Zinc sorption by different soils as affected by selective removal of carbonates and hydrous oxides. Appl. Geochem. 2018, 88, 49-58. [CrossRef]

150. Cakmak, I.; Kutman, U.B. Agronomic biofortification of cereals with zinc: A review. Eur. J. Soil Sci. 2018, 69, 172-180. [CrossRef]

151. Peijnenburg, W.J.; Zablotskaja, M.; Vijver, M.G. Monitoring metals in terrestrial environments within a bioavailability framework and a focus on soil extraction. Ecotoxicol. Environ. Saf. 2007, 67, 163-179. [CrossRef]

152. Norouzi, S.; Khademi, H.; Cano, A.F.; Acosta, J. Using plane tree leaves for biomonitoring of dust borne heavy metals: A case study from Isfahan, Central Iran. Ecol. Indic. 2015, 57, 64-73. [CrossRef]

153. Demková, L.; Árvay, J.; Bobulská, L.; Tomáš, J.; Stanovič, R.; Lošák, T.; Harangozo, L.; Vollmannová, A.; Bystrická, J.; Musilová, J.; et al. Accumulation and environmental risk assessment of heavy metals in soil and plants of four different ecosystems in a former polymetallic ores mining and smelting area (Slovakia). J. Environ. Sci. Health Part A 2017, 52, 479-490. [CrossRef] [PubMed]

154. Galati, A.; Schifani, G.; Crescimanno, M.; Vrontis, D.; Migliore, G. Innovation strategies geared toward the circular economy: A case study of the organic olive-oil industry. RivISTA. Studi Sulla Sostenibilita 2018, 2018, 137-158. [CrossRef]

155. Galati, A.; Gristina, L.; Crescimanno, M.; Barone, E.; Novara, A. Towards More Efficient Incentives for Agri-environment Measures in Degraded and Eroded Vineyards. Land Degrad. Dev. 2015, 26, 557-564. [CrossRef]

156. International Organization for Standardization. ISO 22000: 2018 Food Safety Management Systems-Requirements for Any Organization in the Food Chain, 2nd ed.; International Organization for Standardization: Geneva, Switzerland, 2018. 